Ocean Sci. Discuss., 8, 1301-1338, 2011

www.ocean-sci-discuss.net/8/1301/2011/

doi:10.5194/osd-8-1301-2011

(c) Author(s) 2011. CC Attribution 3.0 License.

\title{
Calculating the water and heat balances of the Eastern Mediterranean basin using ocean modelling and available meteorological, hydrological, and ocean data
}

M. Shaltout ${ }^{1, *}$ and A. Omstedt ${ }^{2}$

${ }^{1}$ Department of Oceanography, University of Alexandria, Alexandria, Egypt

${ }^{2}$ Department of Earth Sciences, University of Gothenburg, Göteborg, P.O. Box 460, 40530, Gothenburg, Sweden

"currently at: Department of Earth Sciences, University of Gothenburg, Göteborg,

P.O. Box 460, 40530, Gothenburg, Sweden

Received: 11 May 2011 - Accepted: 19 May 2011 - Published: 14 June 2011

Correspondence to: M. Shaltout (mohamed.shaltout@gvc.gu.se)

Published by Copernicus Publications on behalf of the European Geosciences Union.

Balances of the Eastern

Mediterranean basin

M. Shaltout and

A. Omstedt

Title Page

Abstract

Introduction

Conclusions

References

Tables

Figures

14

4

Back

Close

Full Screen / Esc

Printer-friendly Version

Interactive Discussion 


\section{Abstract}

This paper analyses the Eastern Mediterranean water and heat balances over a $52-y r$ period. The modelling uses a process-oriented approach resolving the onedimensional equations of momentum, heat, and salt conservation, with turbulence

5 modelled using a two-equation model. The exchange through the Sicily Channel connecting the Eastern and Western basins is calculated from satellite altimeter data. The results illustrates that calculated surface temperature and salinity follow the reanalysed data well and with biases of $-0.4{ }^{\circ} \mathrm{C}$ and -0.004 , respectively. Monthly and yearly temperature and salinity cycles are also satisfactory simulated. Reanalysed data and 10 calculated water mass structure and heat balance components are in good agreement, indicating that the air-sea interaction and the turbulent mixing are realistically simulated. The study illustrates that the water balance in the Eastern Mediterranean basin is controlled by the difference between inflows/outflows through the Sicily Channel and by the net precipitation rates. The heat balance is controlled by the heat loss from the 15 water surface, sun radiation into the sea, and heat flow through the Sicily Channel, the first two displaying both climate trends. An annual net heat loss of approximately $9 \mathrm{~W} \mathrm{~m}^{-2}$ was balanced by net heat in flow through the Sicily Channel.

\section{Introduction}

The Global Energy and Water Experiment (GEWEX) were developed within the World Climate Research Programme (WCRP). Within GEWEX, continental-scale experiments were initiated that included the Baltic Sea drainage basin. In the Baltic Sea experiment (BALTEX), several improvements have been developed with regard to scientific understanding, observations, and modelling considerations (Raschke et al., 2001; Omstedt et al., 2004).

25 New initiatives are now being taken in the Mediterranean region, where climate change may pose a severe threat. Within the HyMex programme (http://www.hymex.

OSD

8, 1301-1338, 2011

Balances of the Eastern

Mediterranean basin

M. Shaltout and
A. Omstedt

Title Page

Abstract Introduction

Conclusions

References

Tables

Figures

14

4

Back

Close

Printer-friendly Version

Interactive Discussion 
org/), the water cycle is of major concern. To support this initiative, we aim to transform knowledge gained from the BALTEX programme so it is applicable to the Mediterranean region. The present paper is the first such initiative and addresses the water and heat balances in the Eastern Mediterranean basin. The approach follows that of 5 Omstedt and Nohr (2004), who used a process-based ocean model together with available meteorological, hydrological, and in situ ocean data to analyse the water and heat cycles.

The Eastern Mediterranean Basin (EMEB), which extends from $11^{\circ} \mathrm{E}$ to $36^{\circ} \mathrm{E}$ and from $30^{\circ} \mathrm{N}$ to $46^{\circ} \mathrm{N}$, is a semi-enclosed basin with negative water balance (i.e. evapora10 tion greater than precipitation plus river runoff). The Sicily Channel (149 km wide) and Strait of Messina ( $4 \mathrm{~km}$ wide) form the connection between the Eastern and Western Mediterranean Sea Basins (Fig. 1). Bosporus-Marmara- Dardanelles system connect Black Sea with EMEB. The exchange through Messina Strait is much smaller than the flow through the Sicily Channel and is therefore neglected. Black Sea will be modelled 15 as a river runoff with a 18 psu smaller than the Mediterranean. The Eastern Mediterranean will be regarded here as a single natural basin with in- and outflows and with focus on processes such as: air sea interaction, land-sea interaction (i.e. river runoff), diapycnal mixing, overturning circulation (Atlantic water inflow modification, Intermediate and deep water formation), exchange through the Sicily Channel and the effect of Black Sea. The Nile River and the Black Sea play an important role in change the fresh water content in the study basin. Intermediate and deep water formations affect the EMED stratification. The model will be driven by available meteorological and hydrological data and validated with available oceanographic data. Based on the calculations, conclusions will be drawn regarding the water (salinity) and heat (temperature) 25 balances.

The thermohaline water structure in the Eastern Mediterranean is an important climate issue, and any changes in it may greatly affect the marine system (e.g. change the deep water formation areas, current system, and sea level, and influences on the ecosystem). Fresh water input to the Eastern basin is mixed with sea surface water.
OSD

$8,1301-1338,2011$

Balances of the Eastern

Mediterranean basin

M. Shaltout and
A. Omstedt

Title Page 
Surface water flows from the Western Mediterranean basin of modified Atlantic water (MAW) through the Sicily Channel are mixed with Eastern basin surface water. Outflow flow water over sill depth $(500 \mathrm{~m})$ is responsible for water loss from the Eastern Mediterranean. The net precipitation rate (precipitation, $P$, minus evaporation, $E$ ) is 5 responsible for salinity increase inside the basin. In winter, and due to evaporation and cooling fluxes, density of Levantine surface water increase further until it become dense enough to forming Levantine intermediate water $(200-500 \mathrm{~m})$ or Levantine deep water.

Roether and Schlitzer (1991) addressed that the average deep water formation rate 10 in the Eastern Mediterranean is about 0.3 Sv. Malanotte-Rizzoli et al. (1999) indicated that deep water formation basically takes place in Adriatic, Aegean and Levantine subbasins. Zervakis et al. (2000) showed that enhanced negative water balance of Eastern Mediterranean leads to new source of deep water formation especially in Aegean Sea.

Béranger et al. (2002) investigated the mean inflow to the Eastern Mediterranean 15 basin through the Sicily Channel using numerical modelling. They estimate that the mean inflow through the Channel is approximately $1.05 \pm 0.35 \mathrm{~Sv}$ for $13 \mathrm{yr}$ period. Stansfield et al. (2002) estimated the surface flow to the Eastern basin using observations from CTD data. They found that there is surface flow of MAW through the Sicily Channel to a depth of $150 \mathrm{~m}$. The outflow of Levantine intermediate water (LIW) through the Sicily Channel takes place in deeper layers. Sorgente et al. (2003) used the Princeton Ocean Model (POM) to study the flow through the Sicily Channel. This modelling detected two main MAW veins, one in the south along the African coast and the other in the north along the Sicilian coast. Based on geostrophic calculation using CTD data from April, 2003 to October, 2003, Ferjani and Gana (2010) indicated that the mean inflow and outflow through western side of Sicily Channel (60 km wide only) were 0.5 and $0.4 \mathrm{~Sv}$ respectively.

Stanev et al. (2000) characterized the water exchange at Bosporus-MarmaraDardanelles system as a two layer flow, where Black Sea water occupies the surface layer (average flow of $0.019 \mathrm{~Sv}$ ) and Mediterranean occupies deep layer (average flow

\section{OSD}

$8,1301-1338,2011$

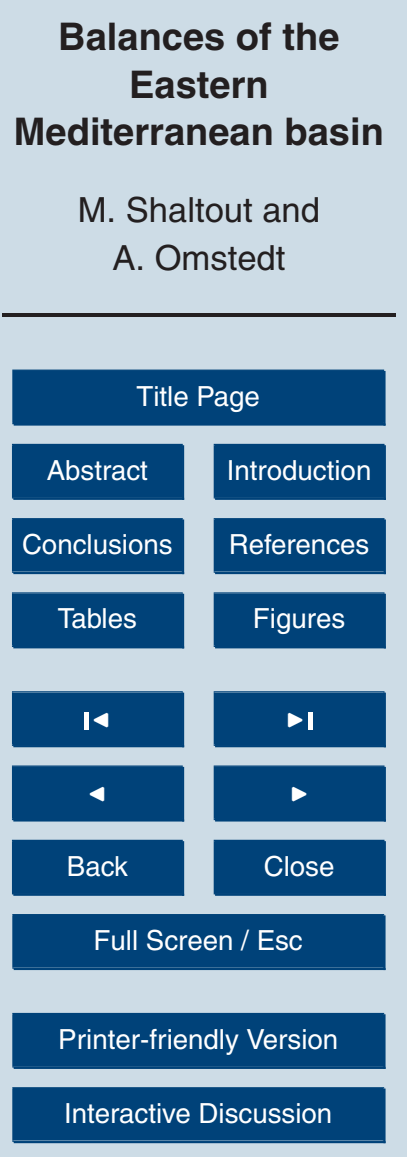

Interactive Discussion 
of $0.009 \mathrm{~Sv}$ ). Recently estimates indicates a reduced inflow by about $0.003 \mathrm{~Sv}$, which affect North Aegean Sea circulation (Stanev and Peneva, 2002).

Nixon (2003) and Ludwig et al. (2009) mentioned that the average discharge of the Nile River to the Mediterranean basin before building Aswan high dam was about 2 5 times higher than after the building.

This paper aims to: (1) examine the water exchange through the Sicily Channel, (2) calculate the long-term change of temperature and salinity distribution in the Eastern Mediterranean basin, and (3) examine the heat and water balances of the Eastern Mediterranean basin.

\section{Material and methods}

\subsection{Modeling forcing data and observations}

Several data sources have been used in this study, they are:

1. Mediterranean Sea absolute dynamic topography data from May 2006 to October 2009 - these data were acquired from the AVISO database available on the internet at http://www.aviso.oceanobs.com/en/home/index.html. Absolute dynamic topography is the sea surface height above the geoid and is calculated as the sum of sea level anomaly and mean dynamic topography. The data were calculated using a one-day temporal scale and $1 / 3^{\circ}$ spatial scale and used to study exchange through the Sicily Channel.

2. Digitized bathymetric data obtained from the British Oceanographic Data Centre with a 0.5 -min grid (http://www.bodc.ac.uk/data/online_delivery/gebco/) - these data were used when calculating the cross-sectional area of the Sicily Channel and the area-depth distribution of the Eastern basin.

3. Data on river runoff into the Eastern Mediterranean basin and the Black Sea over the 1976-1987 periods taken from the SAGE Center for Sustainability and the

OSD

8, 1301-1338, 2011

Balances of the Eastern

Mediterranean basin

M. Shaltout and

A. Omstedt

Title Page

Abstract

Introduction

Conclusions

References

Tables

Figures

14

4

Back

Close

Full Screen / Esc

Printer-friendly Version

Interactive Discussion
$>$ I on 
Global Environment (www.sage.wisc.edu) together with Ludwing et al. (2009) river database over 1958-2000 period - the data were used as forcing for the model simulations.

4. Data on sea surface temperature, air temperature at a height of $2 \mathrm{~m}\left({ }^{\circ} \mathrm{C}\right)$, hori-

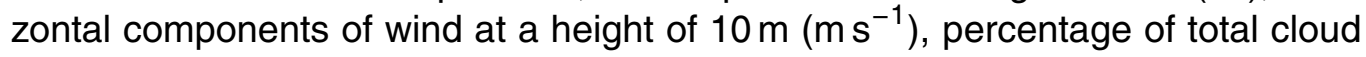
cover, precipitation, and relative humidity for the Eastern Mediterranean basin were extracted from ECMWF Data Server for meteorological data with 6-h temporal resolutions. These data have spatial resolution of $2.5^{\circ} \times 2.5^{\circ}$ and $1.5^{\circ} \times 1.5^{\circ}$ over 1958-1988 and 1989-2009 period respectively.

5. Evaporation rates for the Eastern Mediterranean basin over the 1958-2009 period extracted at $6-\mathrm{h}$ intervals with a $2.5^{\circ} \times 2.5^{\circ}$ spatial resolution - these data were obtained using the NCEP meteorological database (http://www.esrl.noaa. gov/psd/data/) and used in the validation study only.

6. The MEDAR annual temperature and salinity reanalyzed database (Rixen et al., 2005) taken with $0.2^{\circ}$ as special resolution from 1958 to 2002. Temperature (1958-2008) and salinity (1958-1998) reanalyzed data for the Mediterranean Basin taken at a 1-month interval with a spatial distribution of $1^{\circ} \times 1^{\circ}$, were obtained from the National Oceanographic Data Center (http://www.nodc.noaa.gov). Both data sets were used to validate the model results.

\subsection{Model description}

The study relies on numerical modelling of the heat and the water balances of the Eastern Mediterranean basin and the water exchange through the Sicily Channel. The model used calculates the horizontally integrated but vertically resolved resolution properties and is thus a transient one-dimensional model with in and out flows controlling the vertical circulation. The exchange through the Sicily Channel was modelled using current speed across the Channel calculated from satellite, evaporation, precipitation and river inflow data. The studied period was from 1958 to 2009.

1306

\section{OSD}

$8,1301-1338,2011$

\section{Balances of the Eastern \\ Mediterranean basin \\ M. Shaltout and
A. Omstedt

\section{Title Page}

\section{Full Screen / Esc}

Printer-friendly Version

Interactive Discussion 
The model simulated the properties of the Eastern Mediterranean basin based on horizontally averaged advective-diffusive conservation equations for volume, heat, momentum, and salinity. A two-equation turbulent model was applied. The model is fully described in Omstedt and Axell (2003); here, however, only one basin with in- and 5 outflows is considered. In the following, the basic equations are outlined:

The transport equations for horizontal momentum read:

$\frac{\partial \rho U}{\partial t}+W \frac{\partial \rho U}{\partial z}=\frac{\partial}{\partial z}\left[\frac{\mu_{\mathrm{eff}}}{\rho} \frac{\partial \rho U}{\partial z}\right]+f \rho V$

$\frac{\partial \rho V}{\partial t}+W \frac{\partial \rho V}{\partial z}=\frac{\partial}{\partial z}\left[\frac{\mu_{\mathrm{eff}}}{\rho} \frac{\partial \rho V}{\partial z}\right]-f \rho U$

$W=\frac{\left(Q_{\text {in }}(Z)-Q_{\text {out }}(Z)\right)}{\operatorname{Area}(Z)}$

10 where, $U$ and $V$ are the current components in east and north directions, respectively, $W$ the vertical velocity calculated from the differences between in- and outflows, $f$ the Coriolis parameter, $\rho$ is the water density, and $\mu_{\text {eff }}$ is the effective dynamic viscosity.

The conservation equation for heat reads:

$\frac{\partial \rho C_{p} T}{\partial t}+W \frac{\partial \rho C_{p} T}{\partial z}=\frac{\partial}{\partial z}\left[\frac{\mu_{\text {eff }}}{\rho \sigma_{\text {eff }}} \frac{\partial \rho C_{p} T}{\partial z}\right]+\Gamma_{\text {sum }}+\Gamma_{h}$

15 Where, $T$ and $C_{p}$ are temperature of sea water and heat capacity respectively. $\sigma_{\text {eff }}$ is the turbulent Prandtl number.

$\Gamma_{\text {sum }}=F_{s}^{w}(1-\eta) e^{-\beta(D-z)}$

$\Gamma_{h}=\rho c_{p}\left(\frac{Q_{\text {in }} T_{\text {in }}}{\Delta V_{\text {in }}}-\frac{Q_{\text {out }} T_{\text {out }}}{\Delta V_{\text {out }}}\right)$
OSD

$8,1301-1338,2011$

\section{Balances of the Eastern \\ Mediterranean basin}

M. Shaltout and

A. Omstedt

Title Page

Abstract

Introduction

Conclusions

References

Tables

Figures

14

4

Back

Close

Full Screen / Esc

Printer-friendly Version

Interactive Discussion 
where, $\Gamma_{\text {sum }}$ and $\Gamma_{h}$ are the source terms associated with sun radiation and in- and outflows, respectively, $\Gamma_{s}^{w}$ the short-wave radiation through the water surface, $\eta$ the infrared fraction of short-wave radiation trapped in the surface layer, and $\beta$ the bulk absorption coefficient of the water. $Q_{\text {in }}\left(Q_{\text {out }}\right)$ is volume fluxes of in (out) flowing water. $5 D$ is the total depth and $z$ the vertical coordinate positive upwards.

The conservation equation for salinity reads:

$$
\begin{aligned}
& \frac{\partial S}{\partial t}+W \frac{\partial S}{\partial z}=\frac{\partial}{\partial z}\left[\frac{\mu_{\text {eff }}}{\rho \sigma_{\text {eff }}} \frac{\partial S}{\partial z}\right]+\Gamma_{S} \\
& \Gamma_{s}=\frac{Q_{\text {in }} S_{\text {in }}}{\Delta V_{\text {in }}}-\frac{Q_{\text {out }} S_{\text {out }}}{\Delta V_{\text {out }}}-\frac{Q_{f} S_{\text {sur }}}{\Delta V_{\text {sur }}}
\end{aligned}
$$

where, $\Gamma_{s}$ is the source term associated with in- and outflows, and $\sigma_{\text {effs }}$ is the turbulent

Schmidt number.

The vertical turbulent transports in the surface boundary layer are calculated using the so-called $k-\varepsilon$ model, which is a two-equation model of turbulence in which transport equations for turbulent kinetic energy, $k$, and its dissipation rate, $\varepsilon$, are calculated. The turbulence model reads:

$$
\begin{aligned}
& 15 \frac{\partial k}{\partial t}+W \frac{\partial k}{\partial z}=\frac{\partial}{\partial z}\left[\frac{\mu_{\mathrm{eff}}}{\rho \sigma_{k}} \frac{\partial k}{\partial z}\right]+\frac{\mu_{\mathrm{eff}}}{\rho}\left[\left(\frac{\partial U}{\partial z}\right)^{2}+\left(\frac{\partial V}{\partial z}\right)^{2}\right]+P_{b}-\varepsilon \\
& \frac{\partial \varepsilon}{\partial t}+W \frac{\partial \varepsilon}{\partial z}=\frac{\partial}{\partial z}\left[\frac{\mu_{\mathrm{eff}}}{\rho \sigma_{t}} \frac{\partial \varepsilon}{\partial z}\right]+C_{1 \varepsilon} \frac{\mu_{\mathrm{eff}}}{\rho} \frac{\varepsilon}{k}\left[\left(\frac{\partial U}{\partial z}\right)^{2}+\left(\frac{\partial V}{\partial z}\right)^{2}\right]+C_{3 \varepsilon} \frac{\varepsilon}{k}-P_{b}-C_{2 \varepsilon} \frac{\varepsilon^{2}}{k} \\
& P_{b}=\frac{\mu_{T}}{\rho}\left(-\frac{g 2 \alpha_{1}\left(T-T_{r}\right)}{\sigma_{T}} \frac{\partial T}{\partial z}+\frac{g \alpha_{2}}{\sigma_{s}} \frac{\partial S}{\partial z}\right) \\
& \frac{\mu_{\mathrm{eff}}}{\sigma_{\mathrm{eff}}}=\frac{\mu}{\sigma}+\frac{\mu_{T}}{\sigma_{T}}
\end{aligned}
$$

OSD

$8,1301-1338,2011$

\section{Balances of the Eastern \\ Mediterranean basin \\ M. Shaltout and
A. Omstedt

\section{Title Page}

\section{4}

\section{Full Screen / Esc}

Printer-friendly Version

Interactive Discussion 
$\mu_{\mathrm{eff}}=C_{\mu} \rho \frac{k^{2}}{\varepsilon}+\rho \sigma_{T} v_{T}^{d}$

$v_{T}^{d}=\alpha N^{-1}$

where $\sigma_{k}$ is the Schmidt number for $k$ and $\sigma_{\varepsilon}$ is the Schmidt number for $\varepsilon ; C_{1 \varepsilon}, C_{2 \varepsilon}$, and $C_{3 \varepsilon}$ are turbulent coefficients and $P_{b}$ is production/destruction due to stratification.

${ }_{5} \alpha, \alpha_{1}, \alpha_{2}$ are constants, $N^{-1}$ is the Buoyancy frequency and $v_{t}^{d}$ is the turbulent deep water eddy viscosity. The model use the general equation solver PROBE which is a well-documented and freely available program for studies of lakes and coastal seas (Omstedt, 2011).

\subsection{Water exchange through the Sicily Channel}

10 To calculate the heat and water balances of the Eastern Mediterranean basin, the water exchange through the Sicily Channel is needed. This exchange is considered a twolayer exchange, comprising surface flow $\left(Q_{\text {in }}\right)$ from the Western Mediterranean basin and a deeper flow $\left(Q_{\text {out }}\right)$ from the Eastern to Western basins over sill depth (150 to $500 \mathrm{~m})$. Surface flow is calculated using surface satellite sea level data $(\eta)$ across the Channel. Climatological oceanographic data are used to calculate the deeper flow.

The surface flow from the Western to the Eastern Mediterranean basin $\left(Q_{\text {in }}\right)$ was calculated as follows:

1. The horizontal distance from northern to southern Sicily Channel was divided into 17 cross-sectional sectors based on sea level spatial distribution $\left(1 / 3^{\circ}\right)$.

2. The surface geostrophic current speed for each sector was calculated based on geostrophic approximation, or

$U_{g}=\frac{-g}{f} \frac{\partial \eta}{\partial y}, V_{g}=\frac{g}{f} \frac{\partial \eta}{\partial x}$ and $W_{g}^{2}=U_{g}^{2}+V_{g}^{2}$

OSD

$8,1301-1338,2011$

Balances of the Eastern

\section{Mediterranean basin}

M. Shaltout and
A. Omstedt

Title Page

Abstract

Introduction

Conclusions

References

Tables

Figures

14

$\rightarrow 1$

4

Back

Close

Full Screen / Esc

Printer-friendly Version

Interactive Discussion 
Where $f$ is the Coriolis parameter, $g$ the gravity force, $U_{g}$ and $V_{g}$ the velocity components in the $x$ and $y$ directions, respectively, and $W_{g}$ the surface geostrophic speed.

- For simplification, we assumed that the depth of surface layer was $150 \mathrm{~m}$ (see, e.g. Stansfield et al., 2002). In addition, the upper $150 \mathrm{~m}$ was divided into five vertical layers of water, each $30 \mathrm{~m}$ deep. We then assumed that the surface current was decreasing linearly toward the bottom of the surface layer.

- A Cartesian grid of the Sicily Channel with an 8.76-km horizontal resolution and 0.03-km vertical resolution was created, and the surface flow from the Western Mediterranean basin was calculated as a summation over the Channel:

${ }_{10} Q_{\mathrm{in}}=\sum_{i=1}^{17} \sum_{j=1}^{5} W n_{i, j} * A_{i, j}$

Where, $W n$ is now the normal cross-Channel component of the geostrophic flow and $A$ is the corresponding cross-sectional area (Fig. 1).

From the water volume conservation throughout the Eastern Mediterranean basin, the rate of surface elevations change can be calculated as

${ }_{15} \quad A_{S} \frac{\partial \eta}{\partial t}=Q_{\text {in }}-Q_{\text {out }}+A_{S}(P-E)+Q_{f}$

Where $A_{s}$ is the Eastern Mediterranean surface area $\left(=1.67 \times 10^{12} \mathrm{~m}^{2}\right)$ and $\left(\frac{\partial \eta}{\partial t}\right)$ is the change in sea level with time. $Q_{f}$ is the river discharge to the basin and calculated as a sum of total amount of river runoff to the Eastern Mediterranean basin and the Black Sea brackish water. In the present model, we assume that the volume fluxes related to surface elevation changes are small relative to the other contributions, which means that the left hand side of Eq. (17) is zero; this is valid for a long-term scale. This equation can therefore be used to calculate $Q_{\text {out }}$.

\section{OSD}

$8,1301-1338,2011$

\section{Balances of the Eastern \\ Mediterranean basin}

M. Shaltout and
A. Omstedt

Title Page

Abstract

Introduction

Conclusions

References

Tables

Figures

14

4

Back

Close

Full Screen / Esc

Printer-friendly Version

Interactive Discussion 
The heat balance of the water body can be calculated according to Omstedt and Nohr (2004) as:

$$
\frac{d H}{d t}=A_{s}\left(F_{\text {in }}-F_{\text {out }}-F_{\text {loss }}\right)
$$

where $H=\iint \rho C_{p} T d z d A_{s}$ is the total heat content of the Eastern Mediterranean, $F_{\text {in }}$ 5 and $F_{\text {out }}$ the heat fluxes associated with in- and outflows through trhe Sicily Channel, respectively, and calculated according to $F_{\text {in }}=\rho C_{p} T_{\text {in }} Q_{\text {in }}$ and $F_{\text {out }}=\rho C_{p} T_{\text {out }} Q_{\text {out }}$, respectively, $T_{\text {in }}$ the surface inflowing temperature from the Western Mediterranean basin, and $T_{\text {out }}$ temperature of the outflow. $C_{p}$ is heat capacity $\left(=4200 \mathrm{~J} \mathrm{~kg}^{-1}{ }^{\circ} \mathrm{C}\right)$. $F_{\text {loss }}$ is the total heat loss through the sea surface $\left(\mathrm{W} \mathrm{m}^{-2}\right)$ and calculated as $F_{\text {loss }}=$

${ }_{10} F_{h}+F_{e}+F_{\text {prec }}+F_{l}+F_{s}^{O}$, where $F_{h}$ is the sensible heat flux, $F_{e}$ the latent heat flux, $F_{\text {prec }}$ heat flux associated with precipitation (neglected in the study), $F_{\text {I }}$ the net long-wave radiation, and $F_{s}^{o}$ the solar radiation to the open water surface. Heat loss from the open sea is calculated as $F_{n}=F_{h}+F_{e}+F_{l}$. Fluxes are negative when going from atmosphere to the ocean.

\subsection{Forcing data and later boundary conditions}

The Eastern Mediterranean basin was modelled using the PROBE equation solver, the present application being called PROBE-EMED. The model used the area-depth distribution of the Eastern Mediterranean Basin and was forced with meteorological and river runoff data. Satellite sea level observations across the Sicily Channel and surface temperature and salinity at the western side of the Channel were used as lateral boundary conditions. Meteorological data including surface air temperatures $\left({ }^{\circ} \mathrm{C}\right)$, surface winds $\left(\mathrm{m} \mathrm{s}^{-1}\right)$, percentage of total cloud cover, and the relative humidity and precipitation rates $\left(\mathrm{m} \mathrm{s}^{-1}\right)$ were used. The air temperature data were corrected for land influence by comparing them with sea surface temperatures. River runoff data is used as fixed values for each month during the all running time and calculated from the available data. Annual average value of river runoff is 5000 and $3800 \mathrm{~m}^{3} \mathrm{~s}^{-1}$ before and

\section{OSD}

$8,1301-1338,2011$

Balances of the Eastern

\section{Mediterranean basin}

M. Shaltout and
A. Omstedt

Title Page

\section{Full Screen / Esc}

Printer-friendly Version

Interactive Discussion 
after 1964 respectively. This is due to building of Aswan high dam and its effect on Nile river discharge. Black Sea is modelled as river runoff. The most significant rivers flow to the Black Sea are Danube $\left(6766 \mathrm{~m}^{3} \mathrm{~s}^{-1}\right)$, Dnieper $\left(1506 \mathrm{~m}^{3} \mathrm{~s}^{-1}\right)$, Rioni $\left(408 \mathrm{~m}^{3} \mathrm{~s}^{-1}\right)$, Dniester $\left(375 \mathrm{~m}^{3} \mathrm{~s}^{-1}\right)$, Kizilirmak $\left.\left(202 \mathrm{~m}^{3} \mathrm{~s}^{-1}\right)\right)$, Sakarya $\left(193 \mathrm{~m}^{3} \mathrm{~s}^{-1}\right)$ and southern Bug $5\left(110 \mathrm{~m}^{3} \mathrm{~s}^{-1}\right)$. Fresh water discharge into the Eastern Mediterranean basin (rivers of Eastern basin plus Black Sea) addressed a negative trend of $\left.-26.14 \mathrm{~m}^{3} \mathrm{~s}^{-1}\right) \mathrm{yr}^{-1}$ due to building of Aswan high dam and increasing in evaporation rates. This may leads to increasing Eastern Mediterranean basin salinity.

Lateral boundary parameters of surface salinity and water temperature were applied 10 representing the southern Tyrrhenian basin. Surface salinity was calculated as monthly means using data obtained from the National Oceanographic Data Center. Surface air temperature was calculated using ECWMF database with $6 \mathrm{~h}$ temporal resolution.

Three years (May 2006 to June 2009) of daily sea level difference across the Sicily Channel were used to calculate daily $Q_{\text {in }}$ values for the same period. The approach as15 sumes that the daily $Q_{\text {in }}$ values is used for the May 2006-June 2009 period and monthly average values of $Q_{\text {in }}$ can be used to cover the rest of the study period (January 1958April 2006). This assumption is reasonable as: (1) tide (which highly influence sea level fluctuation) is a periodic parameter; (2) the difference between the monthly average values of surface temperature and salinity for the eastern and western side of the Sicily Channel are small; and (3) the vertical difference in the Eastern Mediterranean basin between surface and $500-\mathrm{m}$-depth salinity is only approximately $0.3 \mathrm{~m}$. In future work, the Mediterranean climate system will be modelled using several coupled subbasin models, which will calculate the Sicily Channel flow as a baroclinic exchange flow. Moreover, we will create another four experiments with the PROBE-EMED model for 1958-2009 to analyse the sensitivity of this assumption. This step will be used to examine the error in modelling the Eastern Mediterranean due to the assumption of $Q_{\text {in }}$ as a fixed monthly variable during the years 1958-2005.
OSD

$8,1301-1338,2011$

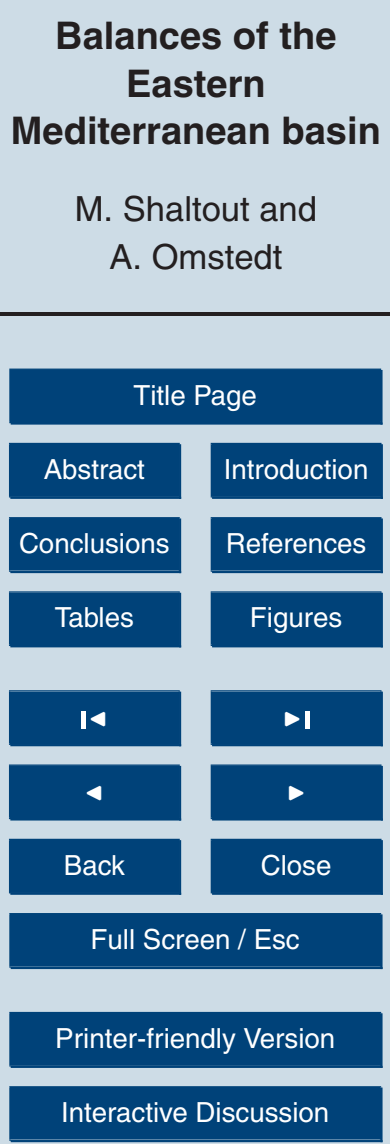

1312 


\subsection{Eastern Mediterranean basin geometry}

Bathymetric information and the area-depth distribution of the studied basin are illustrated in Figs. 1 and 2. The surface area is $1.67 \times 10^{12} \mathrm{~m}^{2}$, the water volume is $2.4 \times 10^{15} \mathrm{~m}^{3}$, the average depth is $1430 \mathrm{~m}$, and the maximum depth is $5097 \mathrm{~m}$. The 5 annual average fresh water runoff is $12943 \mathrm{~m}^{3} \mathrm{~s}^{-1}$, and average precipitation and evaporation are 1.58 and $3.76 \mathrm{~mm}_{\text {day }}{ }^{-1}$, respectively. Moreover, average monthly surface salinity and water temperature over the entire basin ranged from 38.3 to 38.8 and 14.8 to $27^{\circ} \mathrm{C}$, respectively.

The cross-sectional area of the Sicily Channel is calculated from bathymetric data 10 (Fig. 2b). This figure illustrates: (1) the Channel width from the southern to the northern parts is approximately $149 \mathrm{~km}$; (2) the southern part of the Channel is deeper than the northern part; (3) the maximum depth across the Channel is $830 \mathrm{~m}$; and (4) the outflow volume flux is concentrated in the southern part.

\section{Results}

\subsection{Water exchange through the Sicily Channel}

Satellite data on the sea level across the Sicily Channel were used to examine surface current flow from the Western to Eastern basins using Eq. (15) (Fig. 3). Figure 3 depicts how the surface current of MAW from the Western to Eastern basins can take various routes, such as:

1. two routes, one in the northern and the other in the southern part of the Channel (Fig. 3a),

2. water transport across the entire Channel (Fig. 3b),

3. water transport concentrated on the northern part (Fig. 3c), and

4. water transport concentrated on the southern part (Fig. 3d).

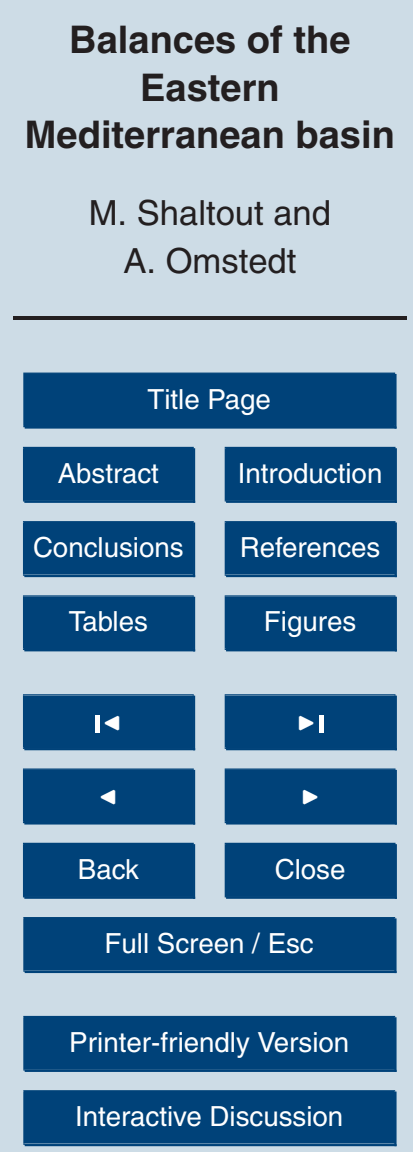


These four routes must be kept in mind when measuring the exchanges. So we shall divide the cross section area across the Channel into small grid size (17 grid cell are used) to get accurate $Q_{\text {in }}$ values. Also, we cannot use only one current meter across the Channel but we have to use series of current meter across the Channel (more than 5 10) which is more difficult. This is why, calculating the exchange across Sicily Channel using satellite data is the best way. Using 17 grids is in agreement with Buongiorno Nardelli et al. (2006) who addressed the mesoscale process importance across the channel.

The temporal variations in the surface- and deep-layer flows are depicted in Fig. 4, 10 showing several features. The surface flow over the period (early June 2006-late June 2009) ranged from 0.25 to $2.56 \mathrm{~Sv}$ with average values of $1.16 \pm 0.34 \mathrm{~Sv}$, while the deep flow ranged from 0.25 to $2.56 \mathrm{~Sv}$ with average values of $1.13 \pm 0.36 \mathrm{~Sv}$. The deep flow (150: $500 \mathrm{~m}$ ) was slightly smaller than surface flow, indicating a loss of water inside the Eastern Mediterranean basin probably due to evaporation. There 15 is a significant difference of $Q_{\text {in }}$ monthly average values. This difference is ranged between $1.4 \pm 0.46 \mathrm{~Sv}$ during April and $0.98 \pm 0.20 \mathrm{~Sv}$ during July. $Q_{\text {in }}$ average value is in good agreement with Béranger et al. (2002) value $(1.05 \pm 0.35 \mathrm{~Sv})$ and larger than Ferjani and Gana (2010) values (by about $0.6 \mathrm{~Sv}$ ). This $0.6 \mathrm{~Sv}$ different with Ferjani and Gana (2010) in calculating $Q_{\text {in }}$ values come from their method that calculating the exchange through the channel from western side to $60 \mathrm{~km}$ wide (not to $149 \mathrm{~km}$ as the present study).

The agreement with Béranger et al. (2002) and Buongiorno Nardelli et al. (2006) and disagreement with Ferjani and Gana (2010) indicates that the present study is useful.

\subsection{Modelling the Eastern Mediterranean basin}

25 Simulating the Eastern Mediterranean basin water and heat cycles was done using the PROBE-EMED model from 1958 to 2009 with a 3-h temporal resolution. Water
OSD

$8,1301-1338,2011$

\section{Balances of the Eastern \\ Mediterranean basin \\ M. Shaltout and
A. Omstedt

\section{Title Page}


masses were modelled using a vertically resolved grid with 190 grid cells, expanding from surface to bottom.

The PROBE-EMED model results were examined by comparing the reanalysed data and modelled long-term monthly surface and 500-m-depth temperatures, surface and 5 500-m-depth salinities, and evaporation (Figs. 5-8). Note that the model simulated data every $3 \mathrm{~h}$, while reanalysed data were based on a $6 \mathrm{~h}$ interval for evaporation and a monthly interval for temperature and salinity. Reanalysed data used for validation were taken as average values for the entire Eastern Mediterranean basin.

The modelled and reanalysed temperature and salinity (MEDAR and NODC 10 datasets) at the surface and at a depth of $500 \mathrm{~m}$ are presented in Figs. 5 and 6, respectively. The modelled surface temperature follows the reanalysed temperature closely with a correlation $(R)$ of $0.98 ; n$ (observations) $=612$, SE (Standard Error) $=$ $0.7^{\circ} \mathrm{C}$ and the average modelled and reanalysed surface temperatures over the study period were $20.65 \pm 3.7^{\circ} \mathrm{C}$ and $20.3 \pm 3.7^{\circ} \mathrm{C}$, respectively. Average modelled and re15 analysed surface salinities were $38.32 \pm 0.14$ and $38.39 \pm 0.13$, respectively $(R=0.6$; $n=540 ; \mathrm{SE}=0.11$ ). This slight difference between modelled and reanalysed salinities may be because the reanalysed data are used 1-yr running window. At a water depth of $500 \mathrm{~m}$, the average modelled and reanalysed temperatures (salinity) over the study period were $14.9 \pm 0.2^{\circ} \mathrm{C}(38.65 \pm 0.16)$ and $14.1 \pm 0.1^{\circ} \mathrm{C}(38.8 \pm 0.05)$, respectively.

The monthly, seasonal, and yearly cycles of surface temperature and salinity were realistically simulated by the model. To investigate the heat balance in greater detail, PROBE-EMED modelled evaporation rates were compared with meteorological modelled evaporation data. For the meteorological data, we now used the NCEP reanalysed data, so an independent dataset was used. Figure 7 depicts the monthly and yearly average values of modelled evaporation rates based on the PROBE-EMED simulations. Figure 8 depicts the scatter plot of modelled and NCEP reanalysed data for the Eastern Mediterranean basin. Over the study period, Modelled evaporation rates ranged from a minimum of 0.2 to a maximum of $11.3 \mathrm{~mm}_{\text {day }}^{-1}$, with an average value of $3.1 \pm 1.5 \mathrm{~mm} \mathrm{day}^{-1}$. The monthly average evaporation rates over the study period
OSD

$8,1301-1338,2011$

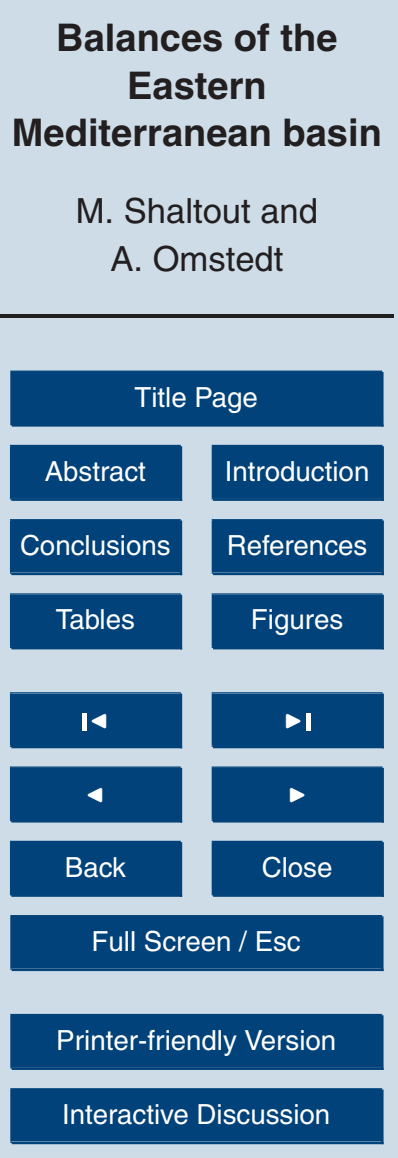

1315 
ranged from $4.95 \pm 1.8 \mathrm{~mm} \mathrm{day}^{-1}$ in August 1985 to $1.31 \pm 0.45 \mathrm{~mm} \mathrm{day}^{-1}$ in May 1993, while the yearly average evaporation rates ranged from 3.26 in 1961 to $2.74 \mathrm{~mm}_{\text {day }}{ }^{-1}$ in 1972. The Reanalyzed and modelled monthly evaporation rates agreed fairly well $\left(R=0.76, n=618, \mathrm{SE}=0.5 \mathrm{~mm} \mathrm{day}^{-1}\right)$.

5 The PROBE-EMED model results for surface temperature, salinity, and evaporation rates were also modelled as monthly means (Fig. 9). This figure indicates that the monthly average surface temperature ranged from $15.8 \pm 0.32^{\circ} \mathrm{C}$ in March to $25.98 \pm 0.44^{\circ} \mathrm{C}$ in August. The monthly average surface salinity ranged from $38.19 \pm 0.09$ in Mai to $38.5 \pm 0.09$ in September. The monthly average evaporation 10 rates over the study period ranged from $1.78 \pm 0.78$ to $3.91 \pm 1.08 \mathrm{~mm}_{\text {day }^{-1}}$ in April and August, respectively. In the summer, surface temperature and evaporation reached their maximum values, as did surface salinity values.

A final test of the water and heat simulations was to investigate the water mass structure in the whole Eastern Mediterranean basin. By comparing modelled and reanalysed data, an independent test of the approach could be performed. The results are presented in Fig. 10a. In this figure, three water masses (i.e. MAW at the surface, LIW at the intermediate level, and deep water) are clearly seen in the $T$-S diagram. Deep water masses are more clearly visible in the reanalysed data than the modelled data. This may be because the Eastern basin has at present only been modelled as 20 a single basin, but will in the future be dived into a number of sub-basins. This figure implies that the deep water formation is partly captured despite the simple approach.

To examine the sensitivity of the PROBE-EMED model and confirm our assumption of $Q_{\text {in }}$ as a fixed monthly variable from 1958 to 2005 and running daily variable from 2006 to 2009 , the results of four sensitivity runs of the model were analysed by adding $25 \pm 15 \%$ and $\pm 50 \%$ of the average value of $Q_{\text {in }}$ (average $Q_{\text {in }}=1.16 \mathrm{~Sv}$ ) to all $Q_{\text {in }}$ values, as shown in Figs. 10-11. We can conclude that any change of $Q_{\text {in }}$ in the $\pm 15 \%$ range indicates insignificant change in the vertical distribution of salinity and temperature. Any change of $Q_{\text {in }}$ in the $\pm 50 \%$ range indicates significant change in salinity distribution and negligible change in temperature. Modelling the Eastern basin from 1958 to 2009
OSD

$8,1301-1338,2011$

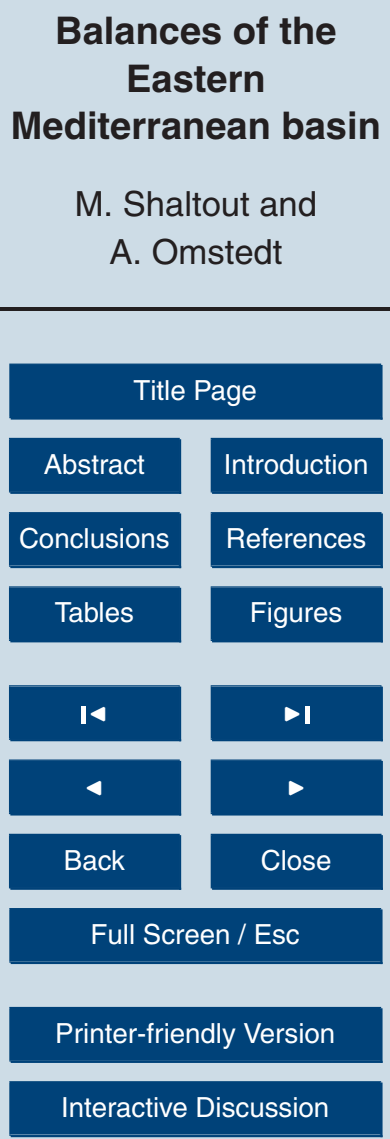

Interactive Discussion 
indicates more sensitivity to meteorological data than to exchange through the Sicily Channel. The Eastern basin may therefore be modelled using a lateral boundary of fixed monthly $Q_{\text {in }}$.

\subsection{Modelled water balance components}

5 The water balance of the Eastern Mediterranean basin is controlled by the Sicily Channel exchange $\left(Q_{\text {in }}\right.$ and $\left.Q_{\text {out }}\right)$, river runoff $\left(Q_{f}\right)$, and net precipitation (difference between precipitation and evaporation rates, Eq. 18). The various water balance components, except precipitation and river runoff, are modelled using the PROBE-EMED model. Table 1 and Fig. 11 show the estimated monthly and annual mean water balances of the Eastern Mediterranean basin averaged over $52 \mathrm{yr}$. Moreover, annual means of the difference between inflow and outflow and the net precipitation flow, i.e. $A_{s}(P-E)$, are shown in Fig. 12.

The results indicate that the in- and outflows are of the order of 1 Sverdrup, while the difference between them is about two orders less. This difference between the in- and outflows was mainly balanced by net precipitation and river runoff. The water balance is thus mainly controlled by the in- and outflows through the Sicily Channel and by net precipitation. The results also indicate that the maximum monthly mean values of $Q_{\text {in }}$ occur in April (1.43 Sv), December (1.28 Sv), and November (1.22 Sv), while $Q_{\text {out }}$ maximum monthly mean values were 1.42, 1.31, and $1.20 \mathrm{~Sv}$, occurring also in April,

20 December, and November, respectively. The monthly net precipitation rates were in the $-0.0068:-0.0679 \mathrm{~Sv}\left(-0.35:-3.5 \mathrm{~mm} \mathrm{day}^{-1}\right)$, reaching a maximum in August and minimum in December. The Eastern Basin monthly mean river runoff varied between a maximum of $0.019 \mathrm{~Sv}$ in April and a minimum of $0.008 \mathrm{~Sv}$ in August, with an annual average of $0.013 \mathrm{~Sv}$. Over the studied 52-yr period, $Q_{\text {in }}-Q_{\text {out }}$ averaged $0.023 \pm 0.84 \mathrm{~Sv}$, 25 while $A_{s}(P-E)$ averaged $-0.03 \pm 0.04 \mathrm{~Sv}$, the difference being balanced by the river discharge.
OSD

8, 1301-1338, 2011

\section{Balances of the Eastern \\ Mediterranean basin \\ M. Shaltout and
A. Omstedt

\section{Title Page}

\section{Full Screen / Esc}

Printer-friendly Version

Interactive Discussion 


\subsection{Modelled heat balance components}

The monthly means of heat budget components are presented in Table 2 and Fig. 14, while the annual means of $F_{n}, F_{s}^{o}$, and $F_{\text {loss }}$ are shown in Fig. 15 . The heat balance simulations indicate that the heat loss from the open sea was almost balanced by the

5 solar radiation to the open water surface. Heat loss from the open sea ranged from $134.9 \mathrm{~W} \mathrm{~m}^{-2}$ to $229.8 \mathrm{~W} \mathrm{~m}^{-2}$, while solar radiation to the open water surface ranged from $-300.3 \mathrm{~W} \mathrm{~m}^{-2}$ in July to $-73.3 \mathrm{~W} \mathrm{~m}^{-2}$ in December. The total heat loss from the Eastern Basin surface was negative (negative fluxes indicate fluxes into the water body) from March to August, while it was positive in the rest of the year. Latent heat flux and net long-wave radiation is important than sensible heat flux in controlling the variability of heat loss from the open sea. The annual average value of $F_{\text {loss }}$ was $8.7 \mathrm{~W} \mathrm{~m}^{-2}$, which needs to be balanced by the difference in heat transported by the in- and outflowing water. During the study period, the annual average value of $F_{n}$ and $F_{s}^{o}$ were $195.6 \mathrm{~W} \mathrm{~m}^{-2}$ and $-186.9 \mathrm{~W} \mathrm{~m}^{-2}$ respectively. Modelled data of $F_{n}$ shows 15 increasing trend of $0.07 \mathrm{~W} \mathrm{~m}^{-2} \mathrm{yr}^{-1}$ while $F_{s}^{o}$ addressed a decreasing trend of about $0.07 \mathrm{~W} \mathrm{~m}^{-2} \mathrm{yr}^{-1}$. The trend thus indicates increased sun radiation into the water body and increased net heat loss, probably due to increased evaporation rates. In addition, the positive values of annual average $F_{\text {loss }}$ imply that the Eastern Mediterranean basin imports heat from the Western basin. Moreover, the figures indicate the close relationship between the meteorological ECMWF data and the present modelled heat balance components (i.e. $F_{n}, F_{s}^{O}$, and $F_{\text {loss }}$ ), with a bias of $4,2.7$, and $3.2 \mathrm{~W} \mathrm{~m}^{-2}$, respectively.

\section{Discussion}

This work analysed the Eastern Mediterranean basin heat (temperature) and water (salinity) balances for the early 1958-June 2009 period in relation to current climate conditions and exchange through the Sicily Channel. The modelling work was based on one-dimensional equations of momentum, heat, and salt conservation, turbulence

OSD

$8,1301-1338,2011$

Balances of the Eastern

Mediterranean basin

M. Shaltout and

A. Omstedt

Title Page

Abstract Introduction

Conclusions

References

Tables

Figures

14

4

Back

Close

Printer-friendly Version

Interactive Discussion 
being modelled using a two-equation model of turbulence. The exchange through the Sicily Channel connecting the Eastern and Western Mediterranean basins was modelled from satellite altimeter data, assuming a geostrophic flow balance. The model was forced with available meteorological and hydrological datasets and the results 5 were validated with independent datasets for salinity, temperature, evaporation and heat fluxes components reanalysed data for the Eastern Mediterranean. Independent datasets of salinity and temperature are taken from MEDAR (annual) and NODC (monthly) reanalyzed datasets while evaporation and heat fluxes components taken from ECMWF dataset.

10 The paper analyses how the individual terms of the water and heat balances change with time and how the climate change signals affect the heat and water cycles. Individual water and heat component values are presented in figures and tables. There are strong monthly and inter-annual variations in most of the water and heat balance components.

15 The most interesting results are (1) climate conditions are dominating the heat and water balances in the eastern Mediterranean than exchange through the Channel, (2) satellite dynamic height observations across the whole channel is a useful and more comprehensive tool to study the exchange through Sicily Channel instead of using series of current meters across the Channel.

20 Modelled surface long-term temperature and salinity follow the reanalysed data with a bias of $-0.4^{\circ} \mathrm{C}$ and -0.004 , respectively. Monthly and yearly cycles of temperature and salinity are well simulated. Reanalysed and modelled water mass structure and heat balance components display good agreement, indicating that the air-sea interaction and turbulent mixing are realistically simulated. The water balance in the

25 Eastern Mediterranean basin is controlled by the difference between the in- and outflows through the Sicily Channel and by the net precipitation rates. The heat balance is controlled by the heat loss from the water surface, sun radiation into the sea, and heat flow through the Channel, the first two displaying both climate trends. An annual net heat loss of approximately $9 \mathrm{~W} \mathrm{~m}^{-2}$ was balanced by net heat flow through the

\section{OSD}

$8,1301-1338,2011$

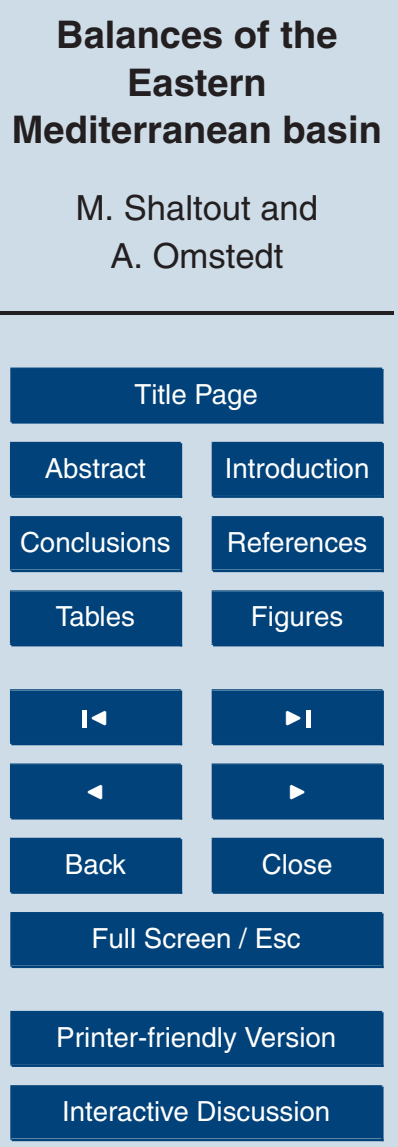

Interactive Discussion 
Channel. Finally, it is clear that using ocean modelling together with meteorological and river runoff data provides a powerful method for simulating heat and water cycles. The water and heat balances, together with trend analysis of a long time series, will be used as climate change tools in future studies.

5 Acknowledgements. This research was undertaken when Mohamed Shaltout was a visiting scientist at the Ocean Climate Group, Department of Earth Sciences, University of Gothenburg, Sweden. Financial support has gratefully been received from the University of Gothenburg and from the Swedish Research Council (contract 621-2007-3750) .

\section{References}

10 Buongiorno Nardelli, B., Cavalieri, O., Rio, M. H., and Santoleri, R.: Subsurface geostrophic velocities inference from altimeter data: Application to the Sicily Channel (Mediterranean Sea), J. Geophys. Res., 111, C04007, doi:10.1029/2005JC003191, 2006.

Béranger, K., Mortier, L., and Crépon, M.: Seasonal transport variability through Gibraltar, Sicily and Corsica Straits. The 2nd Meeting on the Physical Oceanography of Sea Straits,

15 Villefranche, 15-19 April, 77-81, 2002.

Ferjani, D. and Gana, S.: Seasonal circulation and mass flux estimates in the western Sicily Strait derived from a variational inverse section model, Deep-Sea Res. I, 57, 1177-1191, 2010.

Ludwig, W., Dumont, E., Meybeck, M., and Heussner, S.: River discharges of water and nutrients to the Mediterranean and Black Sea: Major drivers for ecosystem changes during past and future decades?, Prog. Oceanogr., 8, 199-217, 2009.

Malanotte-Rizzoli, P., Manca, B., d'Alcala, M., Theocharis, A., Brenner, S., Budillon, G., and Ozsoy E.: The eastern Mediterranean in the 80 s and in the 90s: the big transition in the intermediate and deep circulations, Dyn. Atmos. Ocean., 29, 365-395, 1999.

Nixon, S. W.: Replacing the Nile: Are Anthropogenic Nutrients Providing the Fertility Once Brought to the Mediterranean by a Great River?, Ambio, 32, 30-39, 2003.

Omstedt, A. and Axell, L. B.: Modeling the variations of salinity and temperature in the large GULFS of the Baltic sea, Cont. Shelf. Res., 23, 265-294, 2003.

Omstedt, A. and Nohr, C.: Calculating the water and heat balances of the Baltic Sea using 400-414, 2004.

OSD

$8,1301-1338,2011$

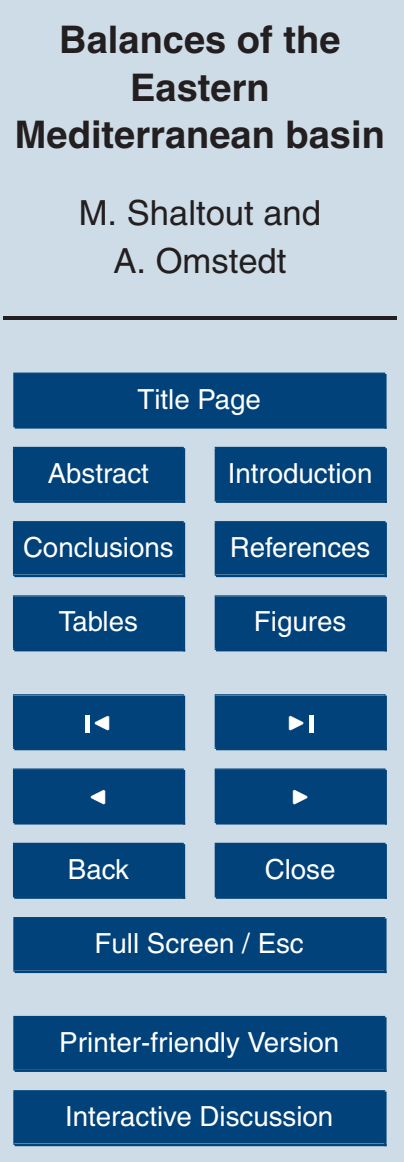

Interactive Discussion 
Omstedt, A., Elken, J., Lehmann, A., and Piechura, J.: Knowledge of the Baltic Sea Physics gained during the BALTEX and related programmes, Prog. Oceanogr., 63, 1-28, doi:10.1016/j.pocean.2004.09.001, 2004.

Omstedt, A.: Guide to process based modelling of lakes and coastal seas, Springer-Praxis books in Geophysical Sciences, doi:10.1007/978-3-642-17728-6, Springer-Verlag Berlin Heidelberg, 2011.

Raschke, E., Meywerk, J., Warrach, K., Andrea, U., Bergström, S., Beyrich, F., Bosveld, F., Bumke, K., Fortelius, C., Graham, L. P., Gryning, S. E., Halldin, S., Hasse, L., Heikinheimo, M., Isemer, H. J., Jacob, D., Jauja, I., Karlsson, K. G., Keevallik, S., Koistinen, J., Van Lammeren, A., Lass, U., Launianen, J., Lehmann, A., Liljebladh, B., Lobemeyr, M., Matthäus, W., Mengelkemp, T., Michelson, D. B., Napiorkowski, J., Omstedt, A., Piechura, J., Rockel, B., Rubel, F., Ruprecht, E., Smedman, A. S., and Stigebrandt, A.:The Baltic Sea Experiment (BALTEX): A European Contribution to the investigation of the Energy and Water Cycle over a Large Drainage Basin, B. Am. Meteorol. Soc., 82, 2389-2413, 2001.

Rixen, J., Beckers, M., Levitus, S., Antonov, J., Boyer, T., Maillard, C., Fichaut, M., Balopoulos, E., Iona, S., Dooley, H., García, M. J., Manca, B., Giorgetti, A., Manzella, G., Mikhailov, N., Pinardi, N., and Zavatarelli, M.: The Western Mediterranean deep water: A proxy for climate change, Geophy. Res. Lett., 32, L12608, doi:10.1029/2005GL022702, 2005.

Roether, W. and Schlitzer, R.: Eastern Mediterranean deep water renewal on the basis of chlorofuoromethans and tritium, Dyn. Atmos. Ocean, 15, 333-354, 1991.

Sorgente, R., Drago, A. F., and Ribotti, A.: Seasonal variability in the Central Mediterranean Sea circulation, Ann. Geophys., 21, 299-322, doi:10.5194/angeo-21-299-2003, 2003.

Stanev, E. V., Le Traon, P. Y., and Peneva, E. L.: Sea level variations and their dependency on meteorological and hydrological forcing: Analysis of altimeter and surface data for the Black Sea, J. Geophys. Res., 105(C7), 17203-17216, 2000.

Stanev, E. and Peneva,E. L.: Regional sea level response to global climatic change: Black Sea examples, Global Planet. Changes, 32, 33-47, 2002.

Stansfield, K., Smeed, D. A., and Gasparini, G. P.: The path of the overflows from the sills in the Sicily Strait, The 2nd Meeting on the Physical Oceanography of Sea Straits, Villefranche, 211-215, 2002.

Zervakis, V., Georgopoulos, D., and Drakopoulos, P.: The role of north Aegean intriggering the recent eastern Mediterranean climatic changes, J. Geophys. Res., 105, 26103-26116, 2000.

\section{OSD}

8, 1301-1338, 2011

\section{Balances of the Eastern \\ Mediterranean basin \\ M. Shaltout and
A. Omstedt

\section{Title Page}

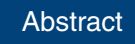

Introduction

Conclusions

References

Tables

Figures

14

$\rightarrow 1$

4

Back

Close

Printer-friendly Version

Interactive Discussion 


\section{OSD}

Table 1. Modelled monthly and annual mean water balance of the Eastern Mediterranean basin averaged over 52 years. Storage is change in Eastern basin volume.

\begin{tabular}{lrrrrrr}
\hline & $\begin{array}{r}Q_{f} \\
(\mathrm{~Sv})\end{array}$ & $\begin{array}{r}P \\
\left(\mathrm{~mm} \mathrm{day}^{-1}\right)\end{array}$ & $\begin{array}{r}E \\
\left(\mathrm{~mm} \mathrm{day}^{-1}\right)\end{array}$ & $\begin{array}{r}A_{S}(P-E) \\
(\mathrm{Sv})\end{array}$ & $\begin{array}{r}Q_{\text {in }} \\
(\mathrm{Sv})\end{array}$ & $\begin{array}{r}Q_{\text {out }} \\
(\mathrm{Sv})\end{array}$ \\
\hline January & 0.014 & 2.80 & 3.24 & -0.009 & 1.03 & 1.02 \\
February & 0.015 & 2.27 & 2.87 & -0.011 & 1.18 & 1.20 \\
March & 0.017 & 1.60 & 2.23 & -0.012 & 1.20 & 1.19 \\
April & 0.019 & 0.95 & 1.79 & -0.016 & 1.43 & 1.42 \\
May & 0.017 & 0.59 & 1.85 & -0.024 & 1.09 & 1.06 \\
June & 0.013 & 0.41 & 2.70 & -0.044 & 1.19 & 1.15 \\
July & 0.009 & 0.30 & 3.70 & -0.066 & 1.09 & 1.04 \\
August & 0.008 & 0.39 & 3.91 & -0.068 & 1.03 & 0.95 \\
September & 0.009 & 1.06 & 3.84 & -0.054 & 1.04 & 0.99 \\
October & 0.009 & 1.89 & 3.58 & -0.033 & 1.20 & 1.17 \\
November & 0.012 & 2.60 & 3.57 & -0.019 & 1.22 & 1.20 \\
December & 0.015 & 3.27 & 3.63 & -0.007 & 1.28 & 1.31 \\
\hline Annual & 0.013 & 1.50 & 3.08 & -0.030 & 1.16 & 1.14
\end{tabular}

$8,1301-1338,2011$

\section{Balances of the Eastern}

\section{Mediterranean basin}

M. Shaltout and
A. Omstedt

\section{Title Page}

\section{Abstract}

Introduction

Conclusions

References

Tables

Figures
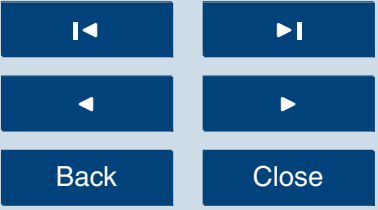

Back

Close

\section{Full Screen / Esc}

Printer-friendly Version

Interactive Discussion 


\section{OSD}

$8,1301-1338,2011$

\section{Balances of the Eastern \\ Mediterranean basin}

Table 2. Estimated monthly and annual means of heat balance components (unit: $\mathrm{W} \mathrm{m}^{-2}$ ).

\begin{tabular}{lrrrrr}
\hline & $F_{h}$ & $F_{e}$ & $F_{l}$ & $F_{s}^{o}$ & $F_{\text {loss }}$ \\
\hline January & 41.10 & 93.69 & 82.55 & -83.03 & 134.33 \\
February & 34.76 & 82.91 & 79.49 & -116.21 & 80.95 \\
March & 22.84 & 64.34 & 72.91 & -168.11 & -8.01 \\
April & 14.07 & 51.72 & 69.08 & -224.78 & -89.91 \\
May & 12.48 & 53.37 & 71.01 & -269.57 & -132.71 \\
June & 17.17 & 78.02 & 78.65 & -297.70 & -123.86 \\
July & 22.18 & 106.93 & 83.03 & -300.32 & -88.18 \\
August & 24.41 & 113.26 & 86.09 & -268.42 & -44.65 \\
September & 26.49 & 111.06 & 88.89 & -208.78 & 17.66 \\
October & 28.11 & 103.56 & 84.44 & -138.39 & 77.71 \\
November & 33.83 & 103.25 & 80.92 & -90.43 & 127.57 \\
December & 41.76 & 104.89 & 83.15 & -73.71 & 156.08 \\
\hline Annual & 26.58 & 88.99 & 80.01 & -186.88 & 8.70
\end{tabular}

M. Shaltout and
A. Omstedt

Title Page

Abstract

Introduction

Conclusions

References

Tables

Figures
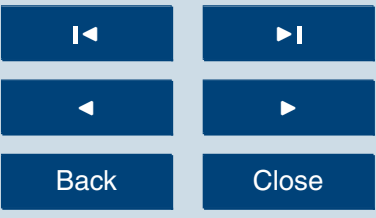

Full Screen / Esc

Printer-friendly Version

Interactive Discussion 


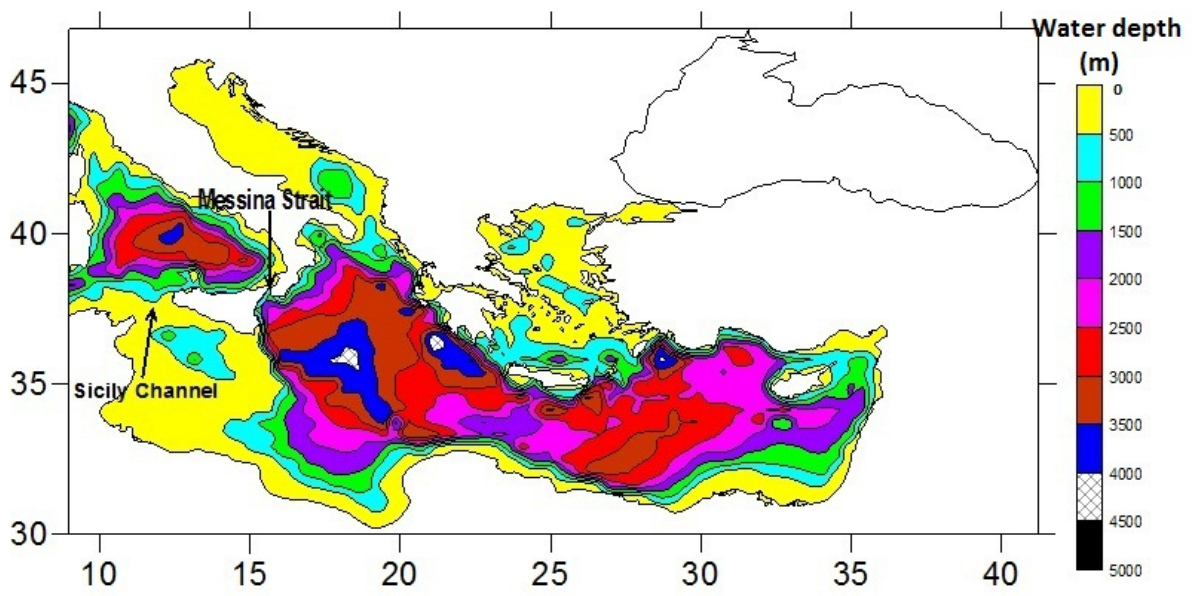

Fig. 1. Bathymetric chart of the Eastern Mediterranean basin.
OSD

$8,1301-1338,2011$

Balances of the Eastern

\section{Mediterranean basin}

M. Shaltout and
A. Omstedt

Title Page

Abstract

Introduction

Conclusions

References

Tables

Figures

14

- I

4

Back

Close

Full Screen / Esc

Printer-friendly Version

Interactive Discussion 

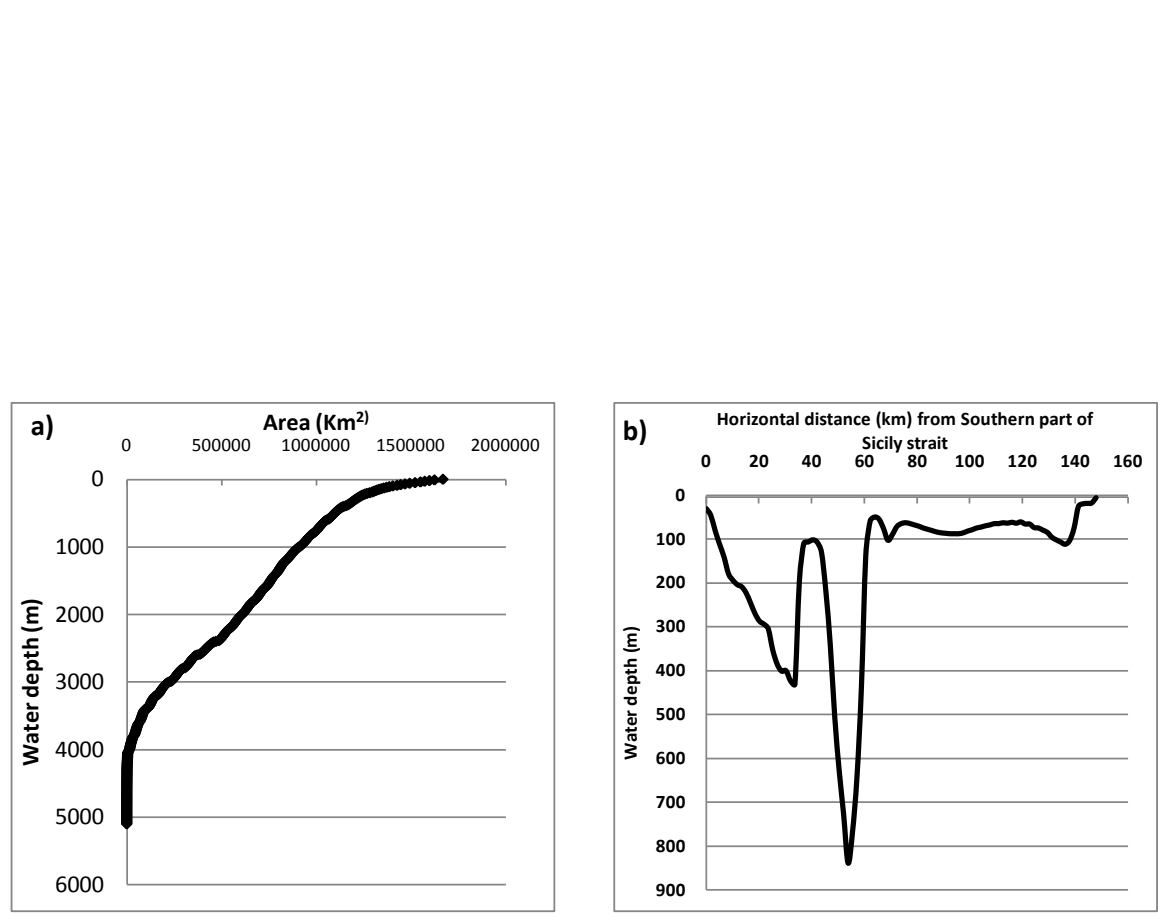

OSD

$8,1301-1338,2011$

\section{Balances of the Eastern \\ Mediterranean basin}

M. Shaltout and
A. Omstedt

Title Page

Abstract

Introduction

Conclusions

References

Tables

Figures

Fig. 2. (a) The area-depth distribution in the Eastern Mediterranean basin. (b) Vertical bathymetric sectors across the Sicily Channel (this sector is plotted in Fig. 1).

14

4

Back

Close

Full Screen / Esc

Printer-friendly Version

Interactive Discussion 


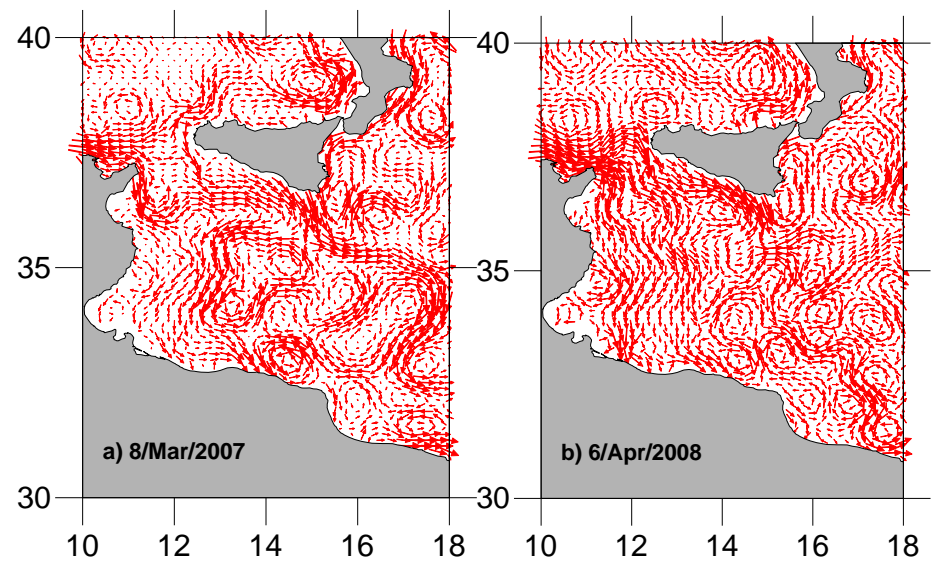

OSD

8, 1301-1338, 2011

\section{Balances of the Eastern \\ Mediterranean basin}

M. Shaltout and

A. Omstedt

Title Page

Abstract

Introduction

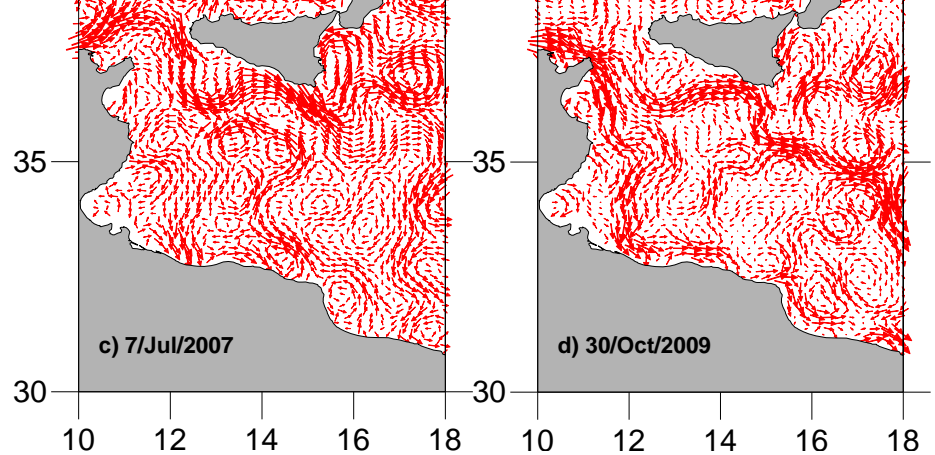

Conclusions

References

Tables

Figures
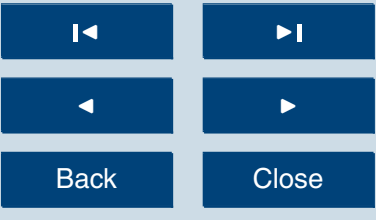

Back

Close

Full Screen / Esc

Fig. 3. Calculated surface geostrophic current speed near the Sicily Channel on four dates (arrow length increases with increasing current speed). These dates were selected to cover all the important transport systems from the Western to Eastern basins.

Printer-friendly Version

Interactive Discussion 
OSD

8, 1301-1338, 2011

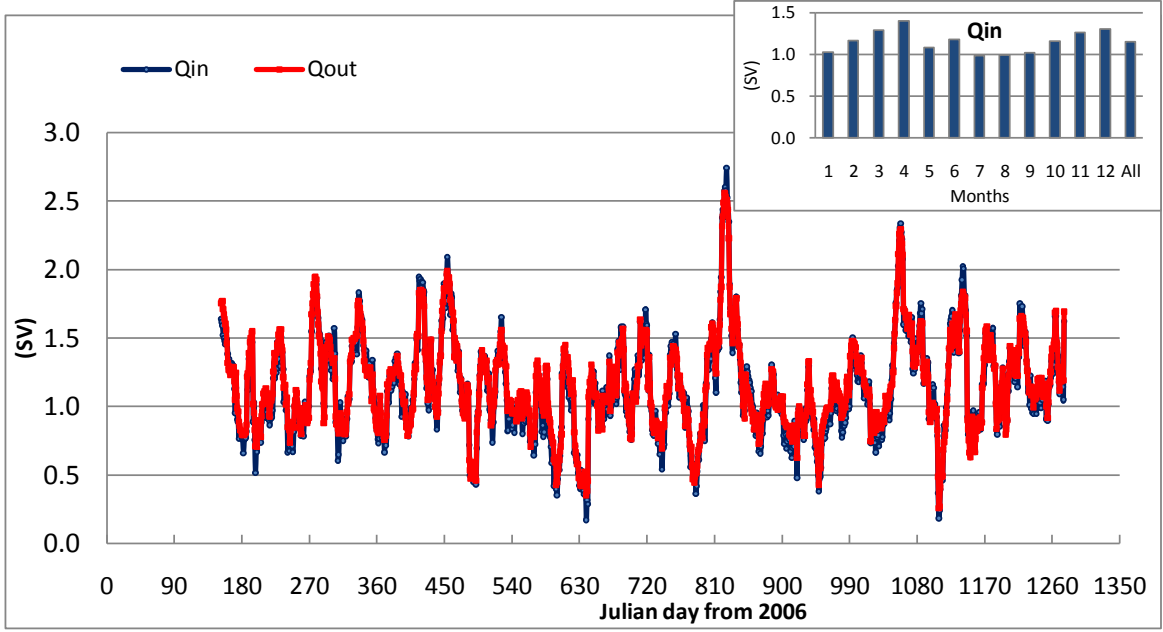

Fig. 4. Time series of average surface flow $\left(Q_{\text {in }}\right)$ and deep out flow $\left(Q_{\text {out }}\right)$ at Sicily Channel. (Monthly average of $Q_{\text {in }}$ in the upper right corner).

\section{Balances of the Eastern \\ Mediterranean basin \\ M. Shaltout and
A. Omstedt

Title Page

Abstract

Conclusions

Tables

14

4

Back

Full Screen / Esc

Printer-friendly Version

Interactive Discussion 
OSD
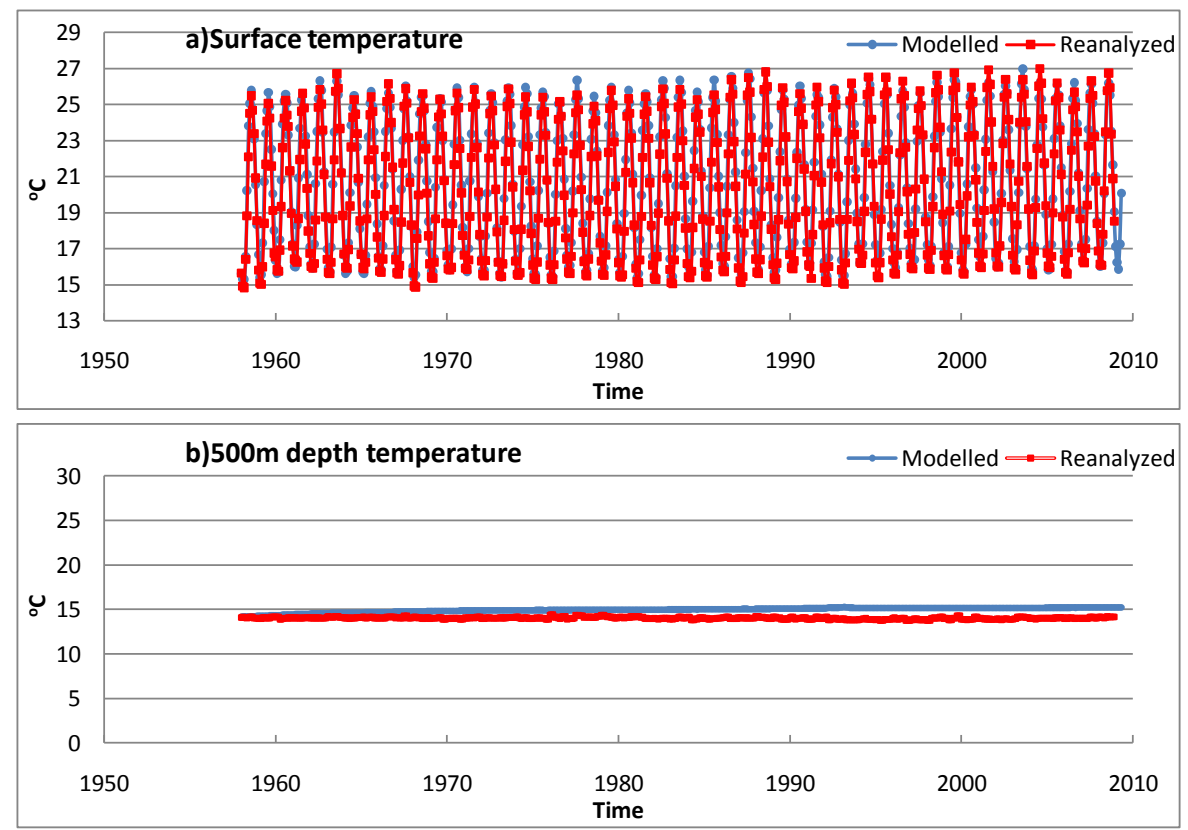

Fig. 5. Reanalysed and modelled temperatures of the Eastern basin.

$8,1301-1338,2011$

\section{Balances of the Eastern \\ Mediterranean basin \\ M. Shaltout and
A. Omstedt

Title Page

\section{Full Screen / Esc}

Printer-friendly Version

Interactive Discussion 
OSD

8, 1301-1338, 2011

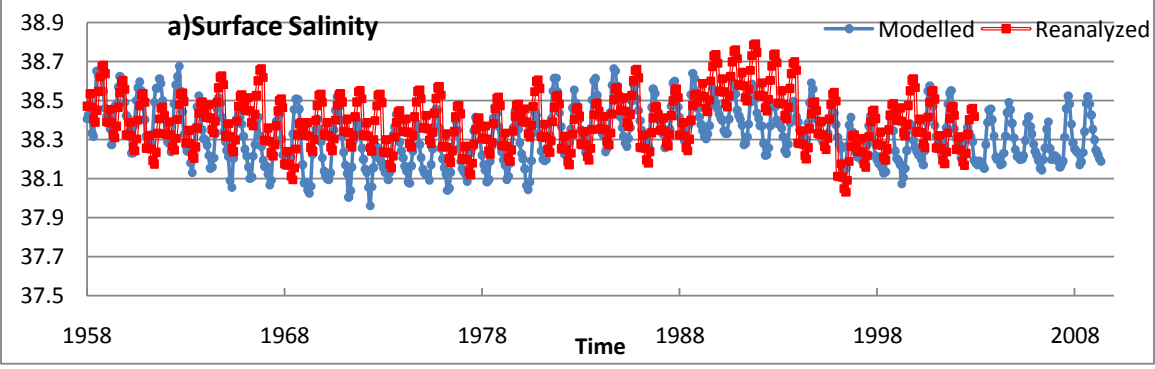

\section{Balances of the} Eastern

\section{Mediterranean basin}

M. Shaltout and
A. Omstedt

Title Page

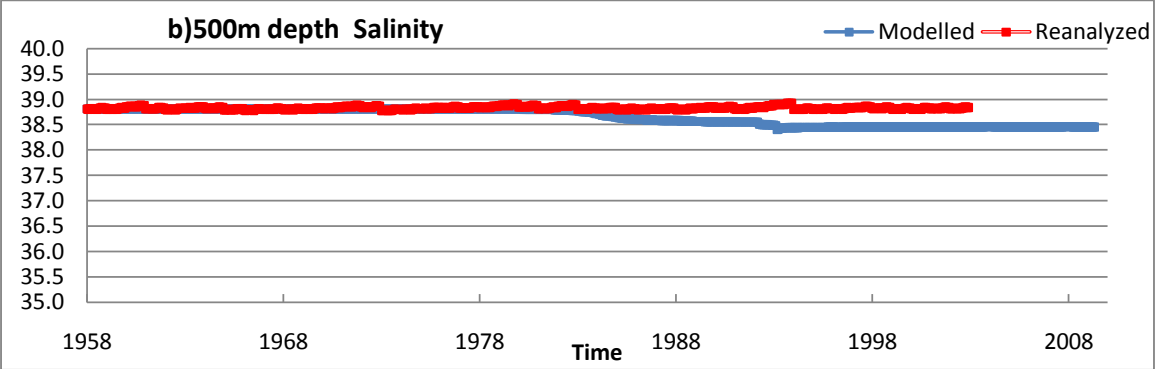

Introduction

Abstract

References

Conclusions

References

Tables

Figures

14

$>1$

4

Back

Close

Full Screen / Esc

Printer-friendly Version

Interactive Discussion 


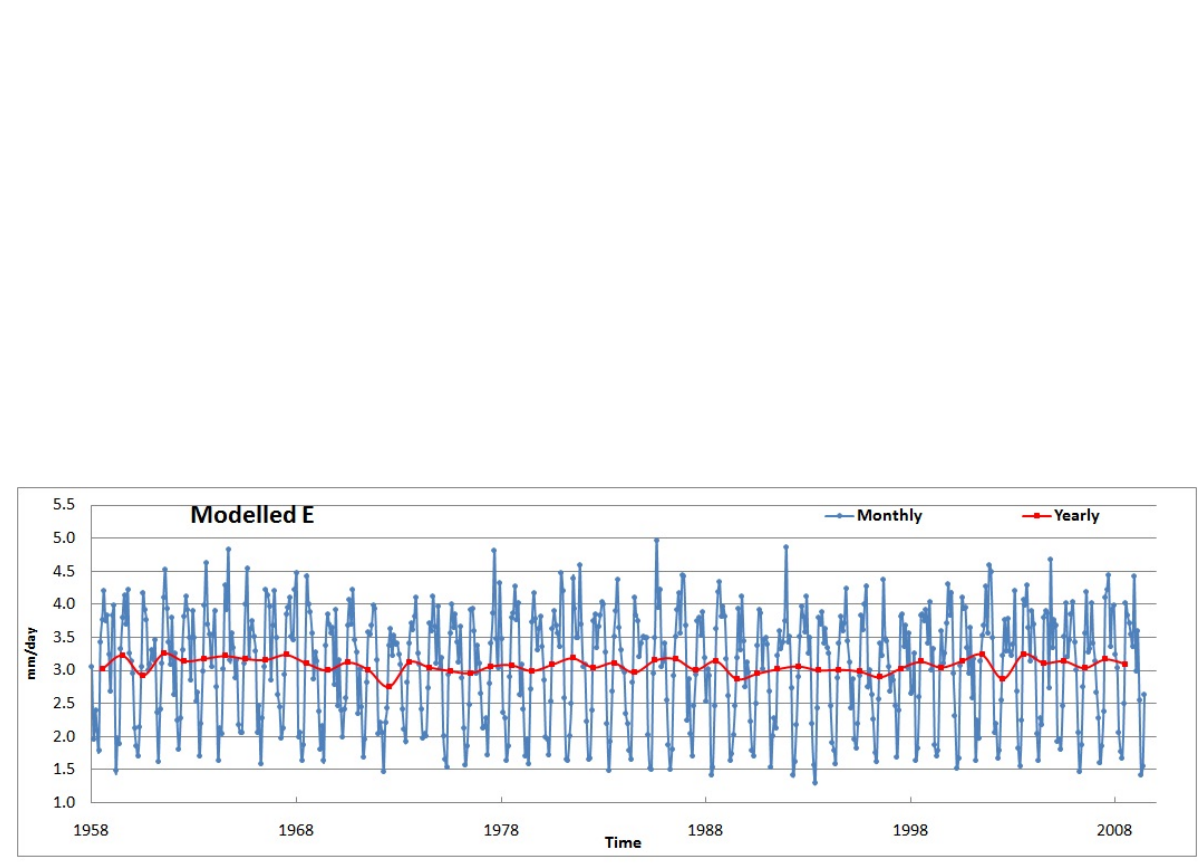

Fig. 7. Modelled monthly and yearly average evaporation $(E)$ rates for the Eastern basin. 


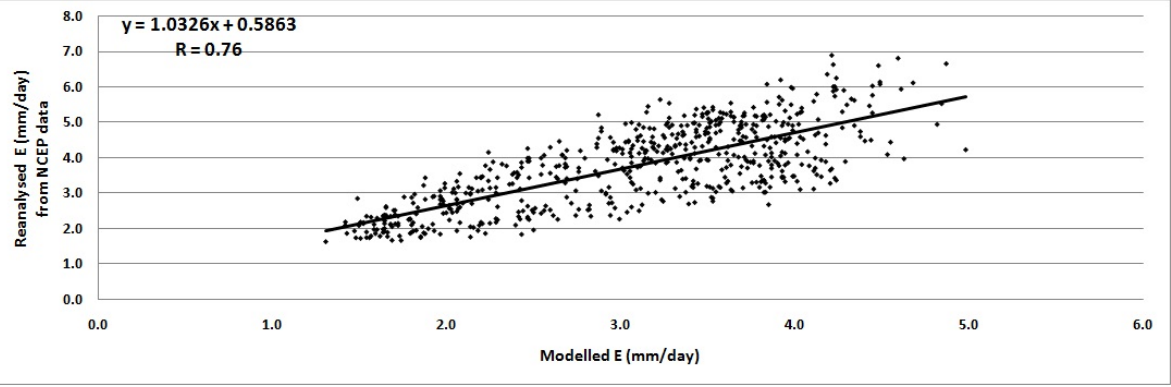

Fig. 8. Monthly scatter plot of evaporation rates calculated from the present ocean model and from the NCEP reanalysed evaporation rates for the Eastern basin.
OSD

$8,1301-1338,2011$

Balances of the Eastern

\section{Mediterranean basin}

M. Shaltout and
A. Omstedt

Title Page

Abstract

Introduction

Conclusions

References

Tables

Figures

14

DI

4

Back

Close

Full Screen / Esc

Printer-friendly Version

Interactive Discussion 

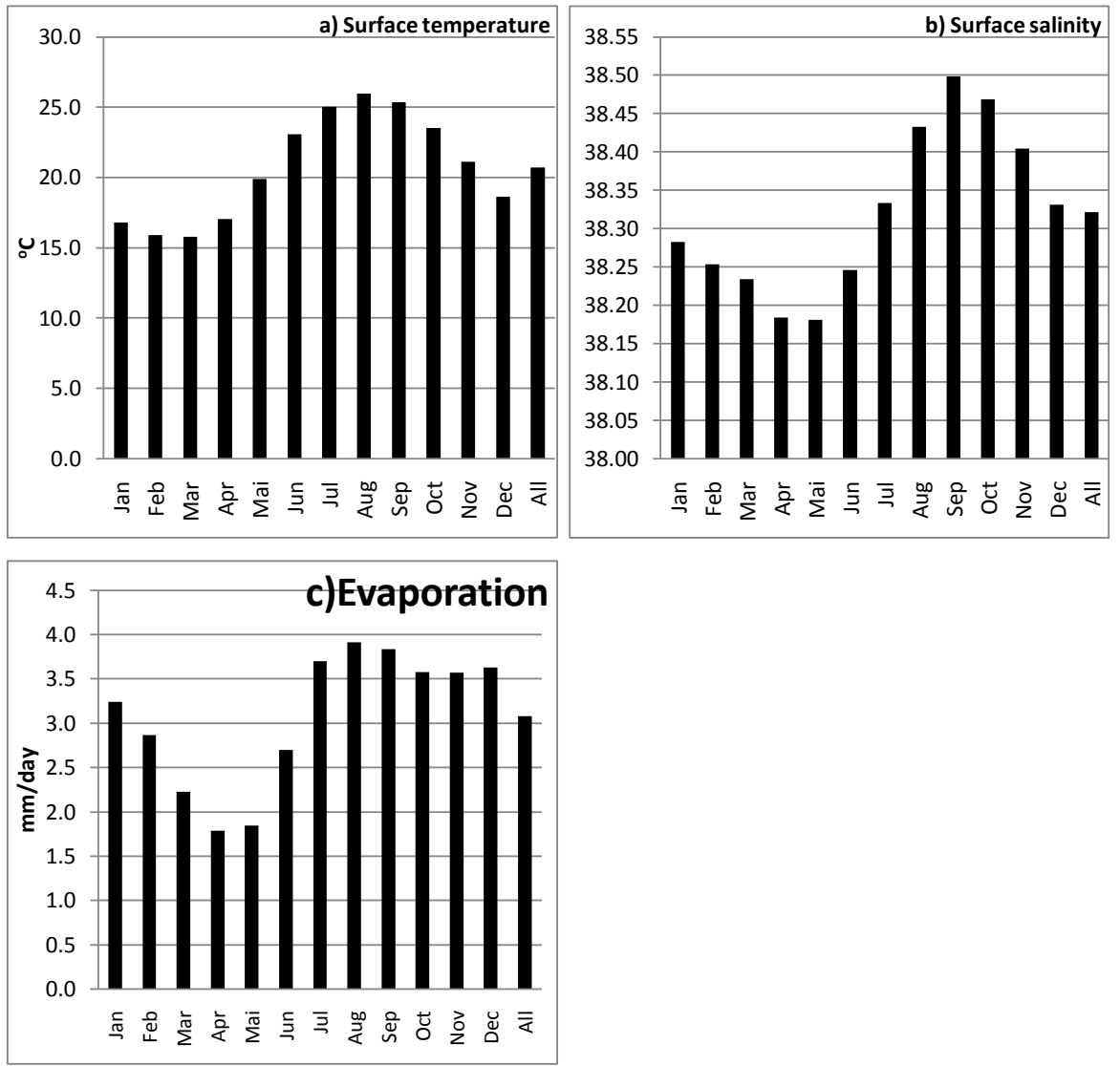

Fig. 9. Monthly average surface temperature (a), salinity (b), and evaporation (c).
OSD

$8,1301-1338,2011$

Balances of the Eastern

\section{Mediterranean basin}

M. Shaltout and

A. Omstedt

Title Page

Abstract

Introduction

Conclusions

References

Tables

Figures

14

Back

\section{Full Screen / Esc}

Printer-friendly Version

Interactive Discussion 

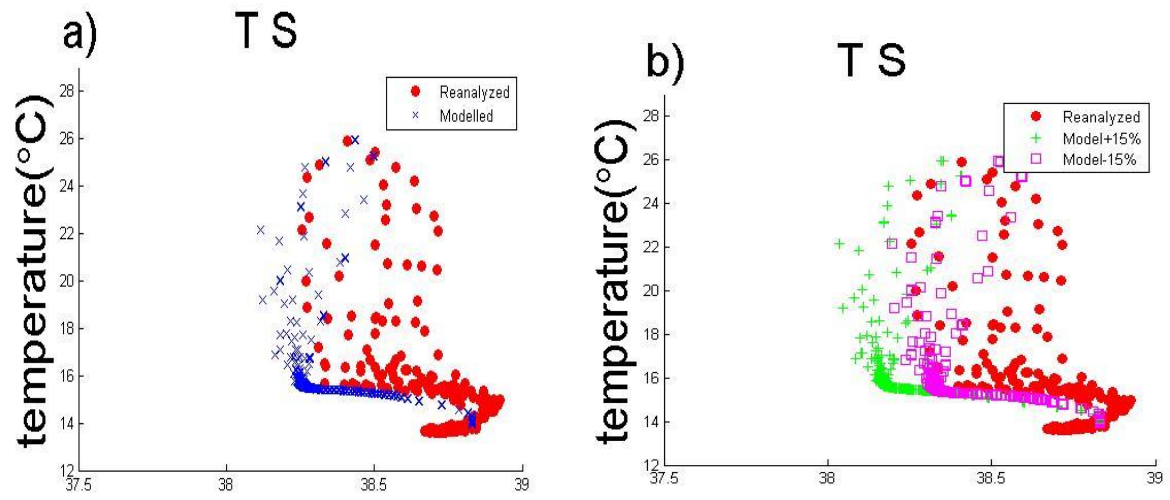

OSD

$8,1301-1338,2011$

\section{Balances of the Eastern \\ Mediterranean basin}

M. Shaltout and
A. Omstedt

Title Page

c) $\mathrm{TS}$

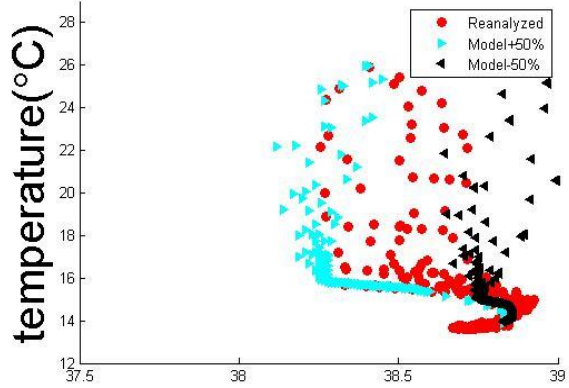

Introduction

Abstract

References

Conclusions

\section{Figures}

Tables

14

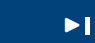

4

Back

\begin{tabular}{|c}
\hline Close \\
\hline
\end{tabular}

Full Screen / Esc

Fig. 10. Monthly $T$-S diagram of the Eastern Mediterranean basin.

Printer-friendly Version

Interactive Discussion 

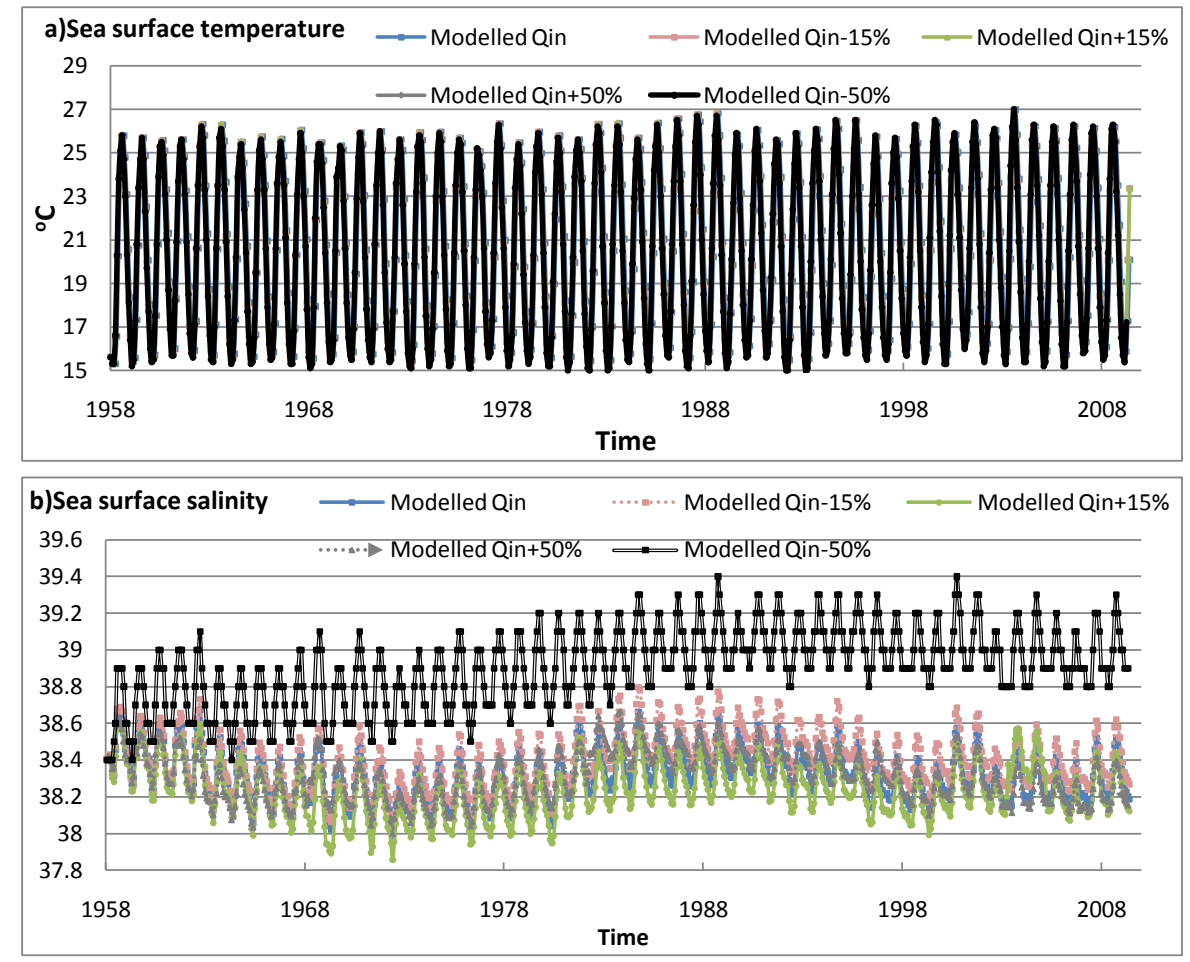

OSD

8, 1301-1338, 2011

\section{Balances of the Eastern \\ Mediterranean basin \\ M. Shaltout and \\ A. Omstedt}

\section{Title Page}

\section{Full Screen / Esc}

Fig. 11. Illustrations of the Eastern Mediterranean modelled surface temperatures (a) and surface salinity (b) to changes in the Sicily Strait flow. 

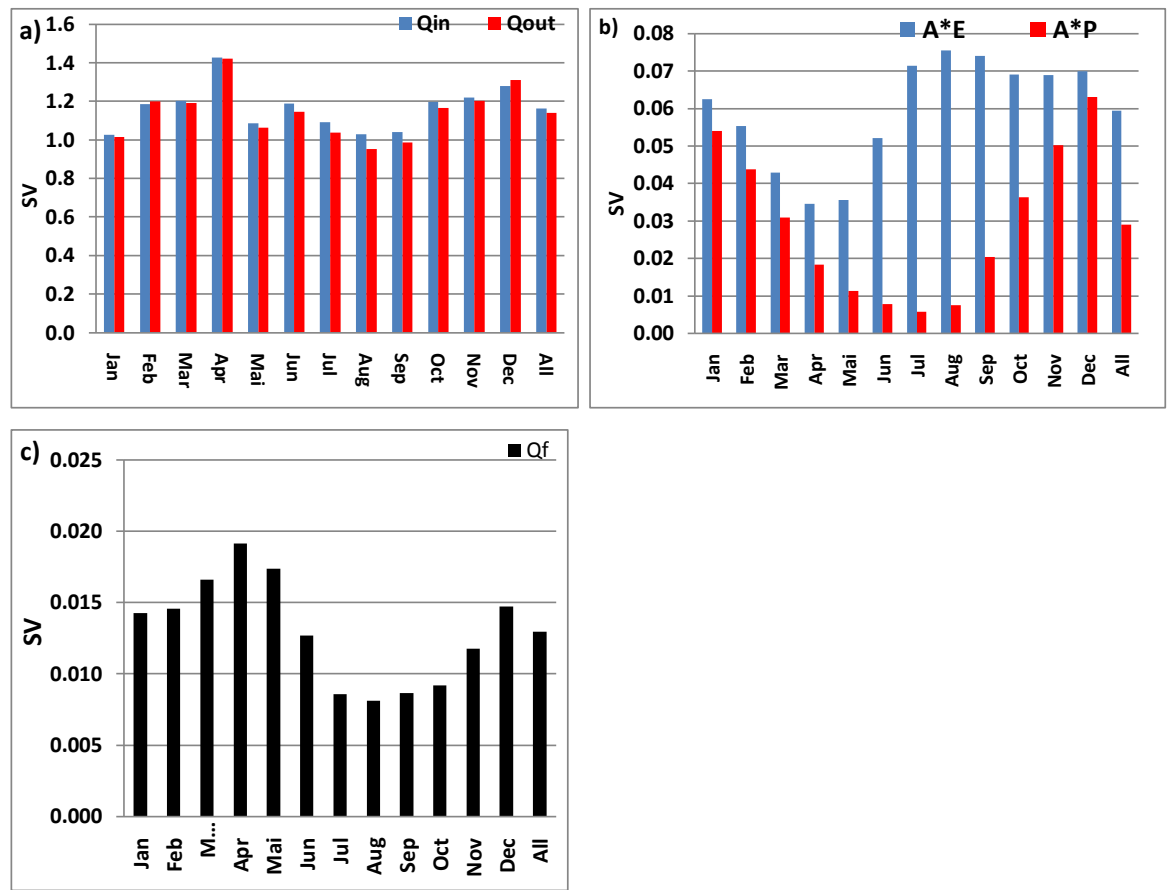

Fig. 12. Eastern Mediterranean basin monthly mean inflow and outflow (a), precipitation and evaporation (b), and river runoff (c).
OSD

$8,1301-1338,2011$

\section{Balances of the Eastern}

\section{Mediterranean basin}

M. Shaltout and

A. Omstedt

Title Page

Abstract Introduction

Conclusions

References

Tables

Figures

14

$>$ I

4

Back

Close

\section{Full Screen / Esc}

Printer-friendly Version

Interactive Discussion 

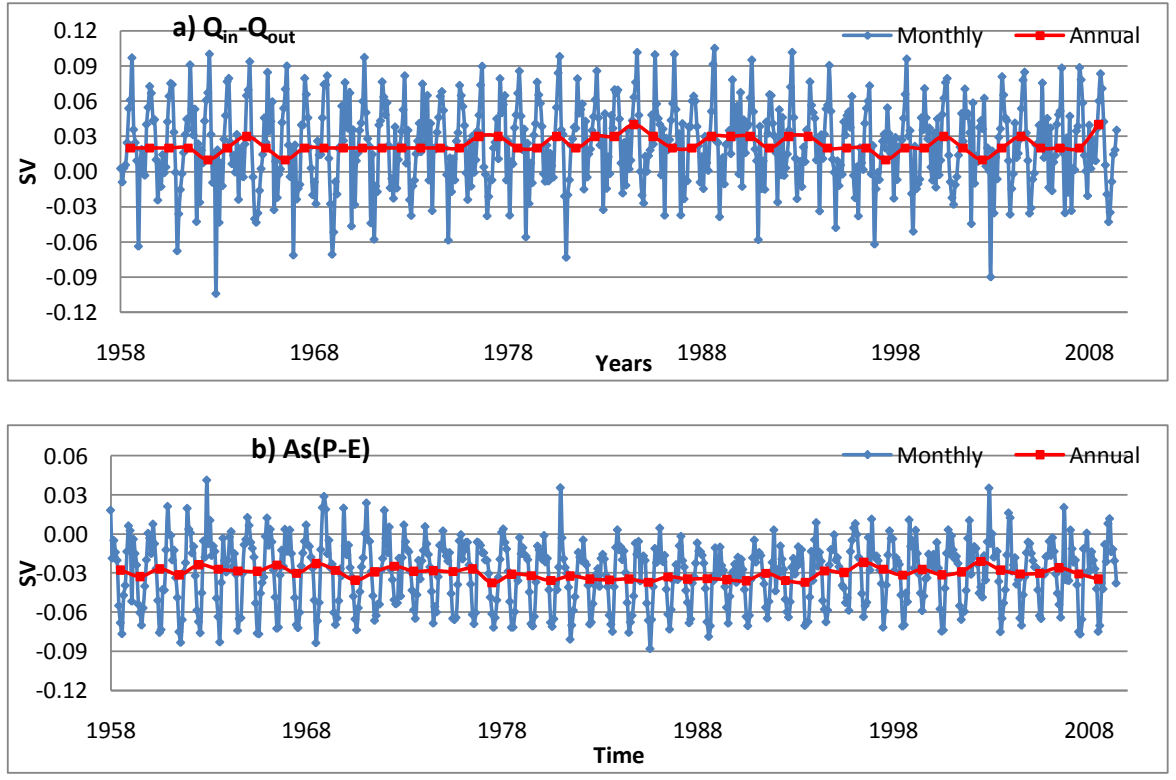

Fig. 13. Eastern Mediterranean basin monthly and annual means of the water balance components: difference between in- and outflows (a) and net evaporation (b).
OSD

$8,1301-1338,2011$

\section{Balances of the Eastern}

\section{Mediterranean basin}

M. Shaltout and
A. Omstedt

Title Page

Abstract

Introduction

Conclusions

References

Tables

Figures

14

$\Delta$

4

Back

Close

Full Screen / Esc

Printer-friendly Version

Interactive Discussion 


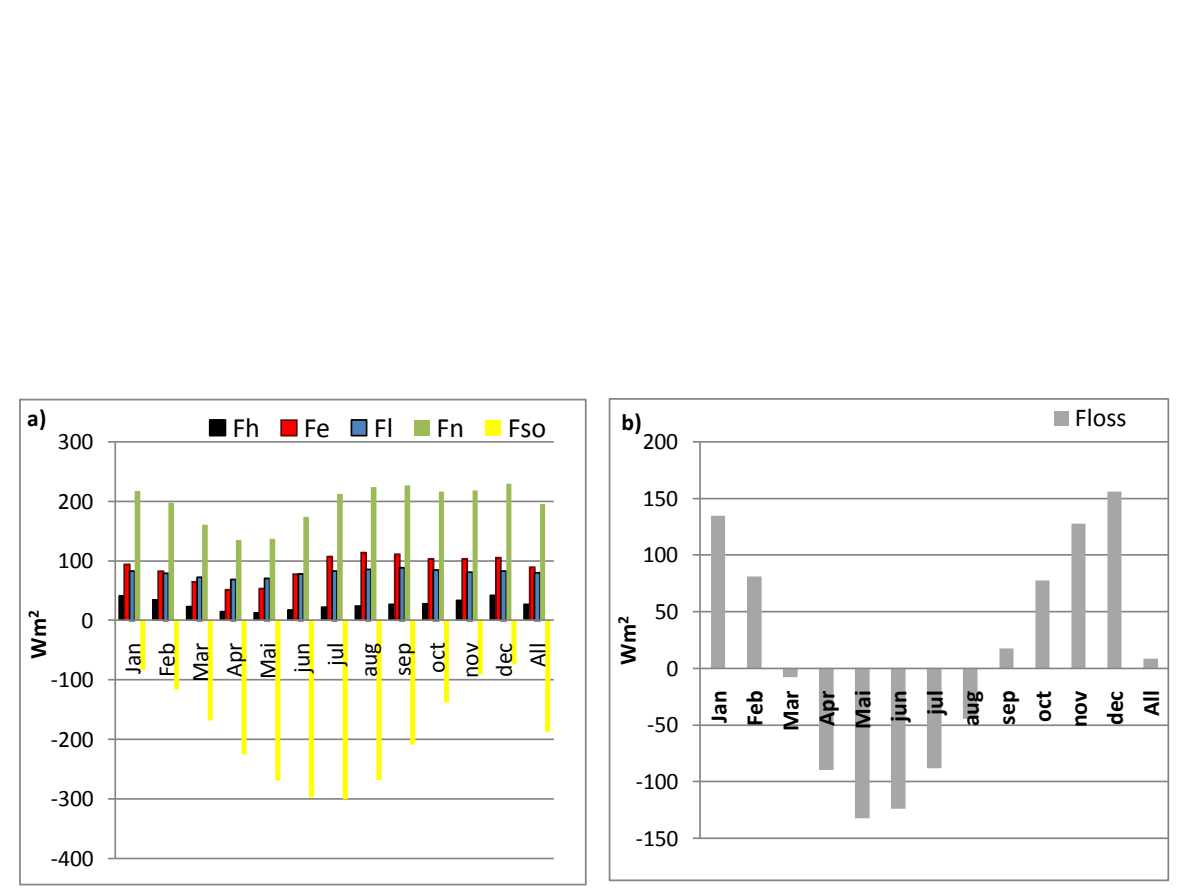

OSD

8, 1301-1338, 2011

\section{Balances of the Eastern \\ Mediterranean basin}

M. Shaltout and
A. Omstedt

Title Page

Fig. 14. Eastern Mediterranean basin monthly heat loss from the open sea $\left(F_{n}\right)$, sensible heat flux $\left(F_{h}\right)$, latent heat flux $\left(F_{e}\right)$, net long-wave radiation $\left(F_{l}\right)$ and solar radiation to the open water surface (negative fluxes indicate fluxes into the water body) (a) and heat loss (b).

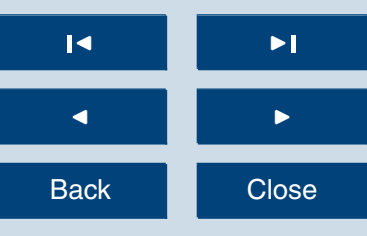

Full Screen / Esc

Printer-friendly Version

Interactive Discussion 

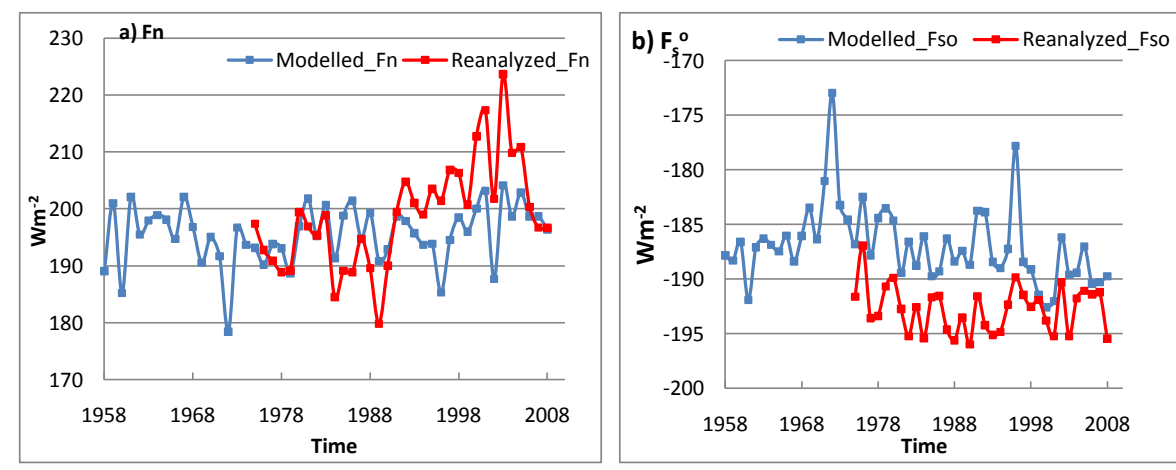

OSD

$8,1301-1338,2011$

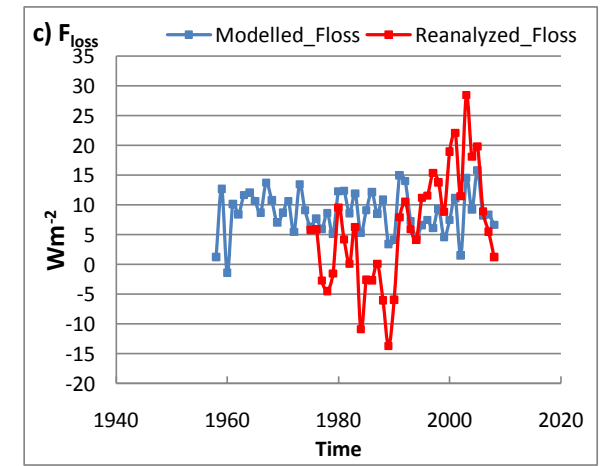

Title Page

Abstract

Introduction

Conclusions

References

Tables

Figures

Fig. 15. Eastern Mediterranean basin annual means for calculated and reanalysed heat balance components: Heat loss from the open sea $\left(F_{n}\right)(\mathbf{a})$, solar radiation to the open water surface $\left(F_{s}^{o}\right) \mathbf{( b )}$, and total heat loss through the sea surface $\left(F_{\text {loss }}\right)$ (c). The modelled values are taken from the present model study, while the reanalysed data were extracted from the meteorological database (ECMWF).

14

4

Back

Close

Full Screen / Esc

Printer-friendly Version

Interactive Discussion 